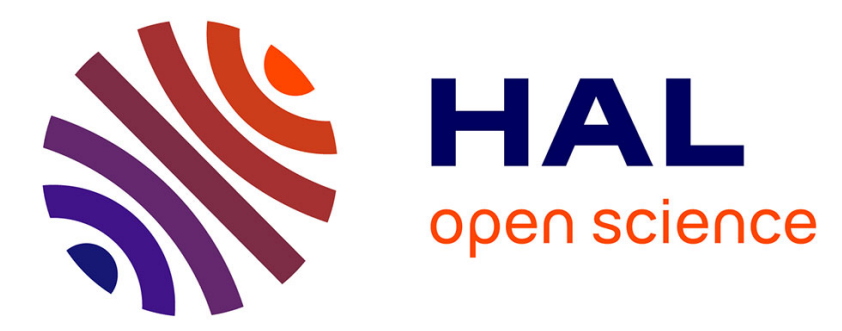

\title{
The impact of freshening on phytoplankton production in the Pacific Arctic Ocean
}

Pierre Coupel, Diana Ruiz-Pino, Marie-Alexandrine Sicre, J. F. Chen, S. H. Lee, N. Schiffrine, H. L. Li, Jean-Claude Gascard

\section{- To cite this version:}

Pierre Coupel, Diana Ruiz-Pino, Marie-Alexandrine Sicre, J. F. Chen, S. H. Lee, et al.. The impact of freshening on phytoplankton production in the Pacific Arctic Ocean. Progress in Oceanography, 2015, 131, pp.113-125. 10.1016/j.pocean.2014.12.003 . hal-01103453

\section{HAL Id: hal-01103453 https://hal.sorbonne-universite.fr/hal-01103453}

Submitted on 14 Jan 2015

HAL is a multi-disciplinary open access archive for the deposit and dissemination of scientific research documents, whether they are published or not. The documents may come from teaching and research institutions in France or abroad, or from public or private research centers.
L'archive ouverte pluridisciplinaire HAL, est destinée au dépôt et à la diffusion de documents scientifiques de niveau recherche, publiés ou non, émanant des établissements d'enseignement et de recherche français ou étrangers, des laboratoires publics ou privés. 
1 The impact of Freshening on phytoplankton production in the

2 Pacific Arctic Ocean

3

4

5

6

7

8

P. Coupel ${ }^{1,2}$, D. Ruiz-Pino ${ }^{2}$, M.A. Sicre ${ }^{2}$, J. F. Chen $^{3}$, S. H. Lee ${ }^{4}$, N. Schiffrine ${ }^{1}$, H.L. Li ${ }^{3}$, J.C. Gascard $^{2}$

${ }^{1}$ Joint International U.Laval-CNRS Laboratory Takuvik, Québec-Océan, Département de Biologie, Université Laval, Québec, Québec G1V0A6, Canada

${ }^{2}$ Sorbonne Universités (UPMC, Université Paris 06)-CNRS-IRD-MNHN, LOCEAN Laboratory, 4 place Jussieu, F-75005 Paris, France

${ }^{3}$ Laboratory of Marine Ecosystem and Biogeochemistry, Second Institute of Oceanography (SIO), State Oceanic Administration (SOA), Hangzhou 310012, China

${ }^{4}$ Department of Oceanography, Pusan National University, 30, Jangjeon-dong, Busan 609-735, South Korea

Corresponding author: Pierre Coupel - Québec-Océan - Pavillon Alexandre-Vachon - Local 2078 - Université Laval - Québec (Québec) G1V 0A6 $\square$ Canada.

Pierre.Coupel@takuvik.ulaval.ca - (418) 6562131 poste 6582

Keyword: Polar waters, primary production, chlorophyll, nitracline, freshening, ice edge, stratification, Arctic Ocean, Canada Basin, Chukchi shelf

\section{Abstract}

Since the 1990's, drastic melting of sea ice and continental ice in the Arctic region, triggered by global warming, has caused substantial freshening of the Arctic Ocean. While several studies attempted to quantify the magnitude of this freshening, its consequences on primary producers remain poorly documented. In this study, we evaluate the impact of the freshwater content (FWC) of the upper Arctic Ocean on phytoplankton across the Pacific sector, from the Bering Strait $\left(65^{\circ} \mathrm{N}\right)$ to the North Pole $\left(86^{\circ} \mathrm{N}\right)$, during summer 2008. We performed statistical analyses on the physical, biogeochemical and biological data acquired during the CHINARE 2008 cruise to investigate the effect of sea-ice melting on the Arctic phytoplankton. We found that the strong freshening observed in the Canada Basin had a negative impact on primary producers as a result of the deepening of the nitracline and the establishment of a subsurface chlorophyll maximum (SCM). In contrast, regions with lower freshening, such as the Chukchi shelf and the marginal ice zone (MIZ) over the Chukchi Borderland, exhibited a shallower nitracline sustaining relatively high primary production and biomass. Our results imply that the predicted increase freshening in future years will likely 
cause the Arctic deep basin to become more oligotrophic because of weaker surface nutrient renewal from the subsurface ocean, despite higher light penetration.

\section{Introduction}

The recent unprecedented decline of Arctic sea-ice cover and ice thickness minimum recorded in September 2007 (Comiso et al., 2008; Perovich, 2011; Stroeve et al., 2011) attracted attention of the international scientific community. With the acceleration of ice melting, environmental factors that are important to primary producers have changed (Wassmann and Reigstad, 2011) with consequences for marine resources and the carbon cycle (Anderson et al., 2010; Bates et al., 2006; Cai et al., 2010; Longhurst, 1991). Among them, the decrease in salinity of the upper Arctic Ocean was particularly notable (Mauritzen, 2012). Freshening was mostly exceptional in the Canada Basin where the freshwater volume increased by $8500 \mathrm{~km}^{3}$ over the last 10 years due to higher sea ice melting, river runoff and stronger Ekman pumping associated with the Beaufort Gyre (McPhee et al., 2009; Rabe et al., 2011). The predicted increase of sea-ice melting and river discharge in the coming years will most likely intensify freshening of the Arctic Ocean (Peterson et al., 2006; Yamamoto-Kawai et al., 2009). One consequence of enhanced freshening is the deepening of the nitracline and chlorophyll maximum, as recently reported by McLaughlin and Carmack (2010) in the interior Canada Basin. According to these authors, on the long-term increased stratification and stronger Ekman pumping would reduce winter nutrient renewal in the euphotic layer and summer primary production. In contrast, the shallow Chukchi shelf waters could become more productive because of a longer productive season (Arrigo et al., 2008; Pabi et al., 2008) and intensification of shelf-break upwellings (Carmack and Chapman, 2003; Lee and Whitledge, 2004). Contrasted responses of phytoplankton inhabiting shelves and deep basins were found by modeling results of cyclone activity in the Pacific Arctic using a coupled biophysical model (Zhang et al., 2014). A biological gain was observed over the shelf while the deep basin showed a loss. However, Yun et al. (2014) showed that in 2009 primary production in the Chukchi shelf waters was negatively affected by freshwater accumulation from Siberian Coastal Current. These results underline that the response of phytoplankton to environmental changes differs spatially owing to bathymetry, sea-ice dynamics, freshwater accumulation and nutrient availability (Ardyna et al., 2011; Carmack and Wassmann, 2006; Poulin et al., 2010). Whether primary production in the shelves and deep basin waters will increase or decrease as a result of ongoing changes in Arctic is still being debated. In this study, we investigate the effects of freshening on chlorophyll- $a$ distribution and primary 
production in the Pacific Arctic Ocean in summer 2008. Biological, chemical and physical data were acquired in a wide area from the Chukchi shelf to the central Arctic, encompassing the Canada Basin and the Chukchi Borderland. This research work is part of the Chinese National Arctic Research Expedition (CHINARE) program, undertaken aboard the icebreaker Xuelong.

\section{Material and Methods}

\subsection{The CHINARE 2008 cruise}

The CHINARE 2008 cruise $\left(1^{\text {st }}\right.$ August $-8^{\text {th }}$ September 2008) took place one year after the large decline of the summer sea-ice cover in 2007 (Perovich et al., 2008; Stroeve et al., 2011). The study area, extending from $65^{\circ} \mathrm{N}$ to $86^{\circ} \mathrm{N}$, includes the shallow Chukchi shelf (depth $<100 \mathrm{~m}$ ) and deep basins (depth $>100 \mathrm{~m}$ ). The ship track encompasses the Chukchi Shelf, Barrow Canyon, Canada Basin, Northwind Ridge and the Alpha Ridge sampled in August 2008, while the Mendeleev Abyssal Plain, Chukchi Cap and Chukchi Abyssal Plain were sampled on the way back in September 2008 (Fig. 1).

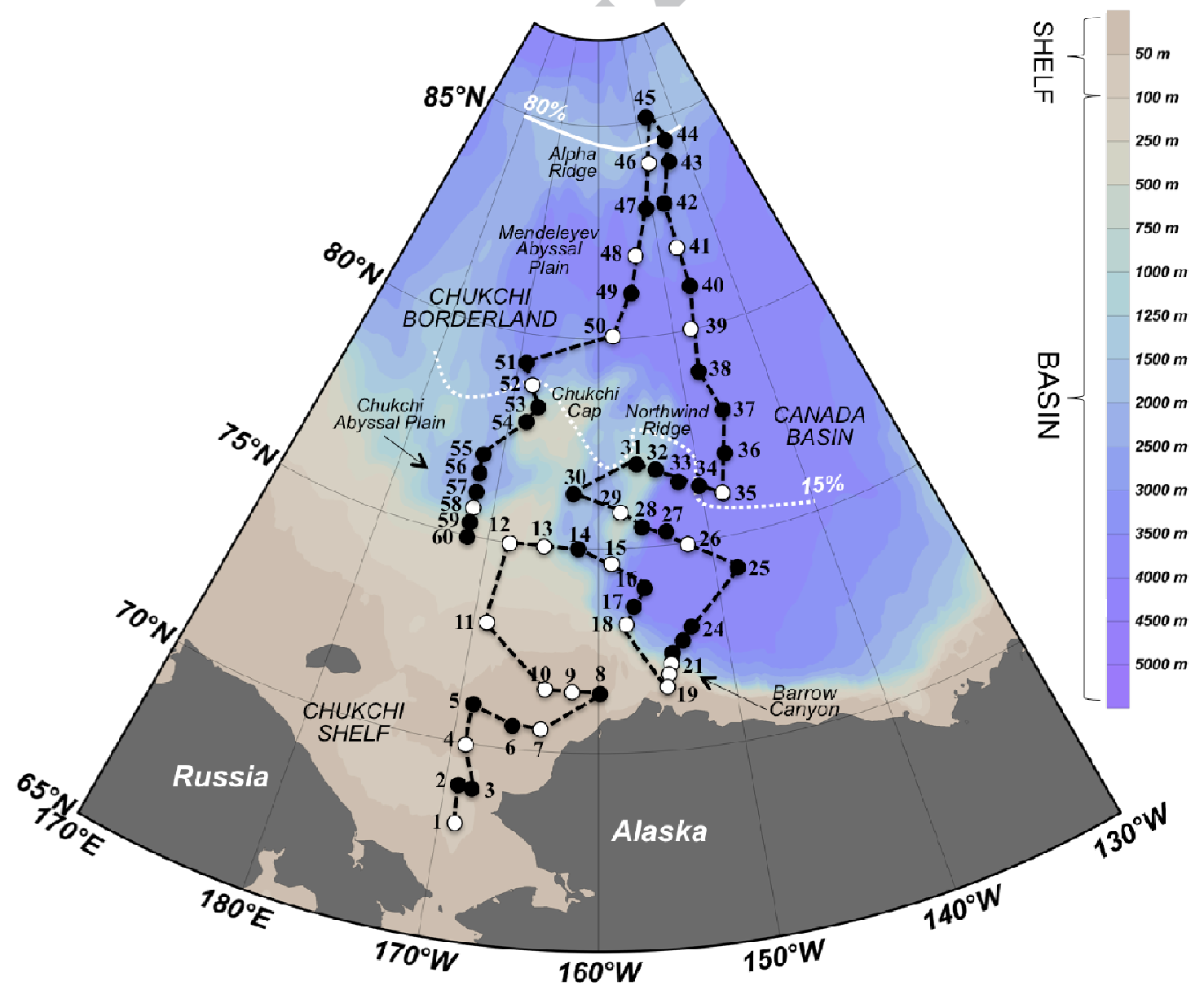


Figure 1. Station number occupied during the CHINARE 2008 cruise aboard the icebreaker XueLong, from August $1^{\text {rst }}$ to September $8^{\text {th }}$, 2008. Stations where nutrients and chlorophyll-a (Chla) were both measured are indicated by black and white dots. Stations where primary production (PP) was also measured are shown by the white dots. The black dashed line represents the ship track. The color scale features the bathymetry and distinguishes the shelf $(<100 \mathrm{~m})$ from the deep basins $(>100 \mathrm{~m})$. The dotted and plain white lines represent the $15 \%$ and $80 \%$ isolines of sea ice cover, respectively, used as lower and upper boundaries of the Marginal ice zone (MIZ).

\subsection{Hydrography and sea ice cover}

Temperature and salinity profiles were acquired at each of the 60 stations of the cruise using a CTD Sea-Bird SBE 911 Plus. Surface sea-ice concentrations were obtained from daily satellite data (level-2 products at $12.5 \mathrm{~km}$ spatial resolution) with the spatial sensor microwave imager (SSM/I). Satellite data for sea ice concentration determination were extracted at each station with the best time and space matching using NASA's SeaDAS image processing software (SeaWiFS Data Analysis System). The freshwater content (FWC) of the upper ocean was calculated to assess the surface water freshening due to sea ice melting and river discharges (McPhee et al., 2009) using the following equation:

$$
F W C=\int_{z_{l i m}}^{0}\left(1-\frac{S(z)}{S_{r e f}}\right) d z
$$

where $S(\mathrm{z})$ is the salinity measured at $\mathrm{z}$ depth, $S_{\text {ref }}$ the reference salinity value, and $z_{\text {lim }}$ the depth at which $S$ equals $S_{\text {ref. }}$ The latter value is taken at 31, which is the salinity minimum of the Pacific Waters entering the Arctic Ocean through the Bering Strait (Woodgate and Aagaard, 2005). This $S_{\text {ref }}$ value therefore precludes freshening caused by the Pacific Waters inflow and allows estimating the freshening due to sea-ice melting $(S=4)$ and rivers discharge $(\mathrm{S}=0$ ) only. Overall, the FWC (in $\mathrm{m}$ ) represents the amount of water needed to account for the negative salinity anomaly relative to 31 .

To determine the influence of the Beaufort gyre and associated Ekman transport, we calculated the dynamic height $D$ (in $\mathrm{m}$ ) between the 0 and $800 \mathrm{~m}$ depth. The reference depth of $800 \mathrm{~m}$ was chosen to reflect the maximum thickness of the water column affected by Ekman transport. The dynamic height between 0 and $800 \mathrm{~m}$ is defined as follows by Thomson and Emery (2001) by:

$$
D(0,800)=\int_{0}^{800} \delta(T, S, p) d p
$$

$\delta(T, S, p) d p$ is the specific volume anomaly corresponding to the difference between in situ density and standard density at the $p$ depth. The standard density is calculated at a salinity of 35 and of temperature of $0^{\circ} \mathrm{C}$. 
120 The stratification of the upper layer was estimated by the stratification index $\left(\mathrm{kg} \mathrm{m}^{-3}\right)$, calculated as the density difference between the surface and $100 \mathrm{~m}$ depth (Codispoti et al., 2005). The polar mixed layer depth (in $\mathrm{m}$ ) was defined as the depth where density $(<$ sigma $>\mathrm{t})$ is $0.05 \mathrm{~kg} \mathrm{~m}^{-3}$ higher than the surface density.

The euphotic depth was determined using three different methods: satellite data, Secchi disk measurements and multispectral data of irradiance. The satellite data were obtained from daily Level 3 Euphotic zone depth products $(9 \mathrm{~km})$ of Aqua MODIS ocean color measurements (http://oceancolor.gsfc.nasa.gov) along the CHINARE 2008 ship track with the best time and space matching using SeaDAS. In the second method, the euphotic depth was calculated as the depth of $1 \%$ of surface light based on Secchi disk measurements in open waters performed on board. The third estimate of the euphotic depth is the depth corresponding to $1 \%$ of surface light values based on Photosynthetically Available Radiation (PAR) calculated from multispectral data (Jinping et al., 2010). The three methods provide similar euphotic depth estimates (not shown). In this study, we used the mean values calculated from these estimates.

\subsection{Nutrients}

Nutrients were measured at all stations (black and white dots in Fig. 1). Four to 10 depths were sampled in the water column with a minimum of 4 levels in the upper $100 \mathrm{~m}$. Nutrient concentrations were determined on board using a $\operatorname{scan}^{++}$Continuous Flow AutoAnalyzer (SKALAR). Nitrate concentrations $\left(\mathrm{NO}_{3}{ }^{-}\right)$were calculated following Wood et al. (1967). Orthosilicic acid $\left(\mathrm{Si}(\mathrm{OH})_{4}\right)$ was measured according to Grasshoff and Ehrhardt (1983) and phosphate $\left(\mathrm{PO}_{4}{ }^{3-}\right)$ as described by Gordon et al. (1993). Primary standards and reagents were prepared according to the World Ocean Circulation Experiment (WOCE) protocol. Analytical precision was $\pm 0.02 \mu \mathrm{M}$ for phosphates and $\pm 0.1 \mu \mathrm{M}$ for nitrates and silicates. To determine the nutrient depletion of the surface layer, we calculated the depth of the nitracline because nitrates are usually the limiting nutrients in the Arctic Ocean (Tremblay et al., 2006). We identified the shallowest depth layer at which the nitrate gradient is higher than $0.1 \mu \mathrm{M} \mathrm{m}^{-1}$. We then calculated the depth of the nitracline as the mid-depth point of this layer. This parameter indicates the availability of nitrates for primary production.

\subsection{Chlorophyll-a and primary production}

Chlorophyll- $a$ concentrations (Chla in $\mathrm{mg} \mathrm{m}^{-3}$ ) were measured at all stations (black and white dots in Fig. 1) by high-performance liquid chromatography (HPLC) performed at the Second Institute of Oceanography, Hangzhou, China (SOA) following the method described in Coupel et al. (2012). The detection limit for Chl $a$ is estimated to be $0.0001 \mathrm{mg} \mathrm{m}^{-3}$. The sub-surface chlorophyll maximum (SCM) was determined as the depth of fluorescence 
maximum based on CTD profiles.

In situ hourly primary production ( $\mathrm{PP}$ in $\mathrm{mg} \mathrm{C} \mathrm{m}^{-3} \mathrm{~h}^{-1}$ ) was determined at 23 stations (white dots in Fig. 1). Six depths were sampled based on PAR values at 100\%, 50\%, 30\%, 12\%, 5\% and $1 \%$ attenuation. The analytical procedure to estimate PP is described by Lee et al. (2010). Briefly, ${ }^{13} \mathrm{C}$ isotope-enriched (98-99\%) $\mathrm{H}^{13} \mathrm{CO}_{3}$ was added to the samples to reach a concentration of $\sim 0.2 \mu \mathrm{M}{ }^{13} \mathrm{CO}_{2}$ and incubated with running surface seawater. The ${ }^{13} \mathrm{C}$ enrichment was about 5-10\% of the total inorganic carbon in ambient water, as determined by titration with $0.01 \mathrm{~N} \mathrm{HCl}$ (Anderson et al., 1999). The PP values were linearly interpolated every meter using the six discrete depth measurements and integrated over the euphotic depth to calculate the integrated daily PP $\left(\mathrm{mg} \mathrm{C} \mathrm{m}^{-2} \mathrm{~d}^{-1}\right)$. The production of carbon by unit Chla (PP/Chl $a$ in $\mathrm{gC} \mathrm{gChl} a^{-1} \mathrm{~h}^{-1}$ ) was calculated by dividing hourly PP by the Chl $a$ concentration. A high PP/Chla ratio indicates efficient carbon fixation by phytoplankton while low index values reflect a poorly efficient carbon fixation.

\subsection{Data multivariate analysis}

Principal component analysis (PCA) is an exploratory statistical method often used to describe a wide array of individuals and variables (Legendre and Legendre, 2012). When individuals are described by a large numbers of variables, simple graphical representation of the correlations existing between variables is not possible. PCA provides a representation in a lower-dimensional space, defined by eigenvectors, of the maximum variance between data. Each eigenvector (PC factor) is a linear combination of variables and is associated with a \% of explained variance.

In this study, PCA was applied on the normalized dataset to evaluate the correlation between physical, chemical and environmental variables such as the bathymetry (in m), FWC, depth of the Pacific Winter Water (PWW), stratification, dynamic height, temperature, sea ice concentration, polar mixed layer, euphotic depth, nitracline depth and the nitrate concentrations in the euphotic depth. The following biological variables, PP, surface Chla, SCM and depth of the SCM, were added as supplementary variables in the analysis. Eigenvectors of similar and opposite directions indicate positive and negative correlation between variables, respectively. These multivariate analyses were performed using the ade 4 package for $\mathrm{R}$ (Chessel et al., 2004).

\section{Results}




\subsection{The physical environment}

\subsubsection{Ice cover and euphotic depth}

During the CHINARE 2008 cruise, the ice cover in the Pacific Arctic Ocean was strongly reduced following the minimum multiyear ice coverage on record, in 2007. The Chukchi shelf was free of ice except for its northern part, which was partially ice-covered (40\% sea ice, Fig. 2a). The ice-free zone (IFZ $<15 \%$ of sea ice) was found as far North as $76^{\circ} \mathrm{N}$ over the Canada Basin in mid-August, and $78^{\circ} \mathrm{N}$ over the Chukchi Cap, end of August. The marginal ice zone (MIZ) extended North of the ice-free waters and up to $84^{\circ} \mathrm{N}$, in areas where sea ice cover ranged from $15 \%$ to $80 \%$, following the criteria of Strong and Rigor (2013). The heavy ice zone (HIZ $>80 \%$ of sea ice) lied North of $84^{\circ} \mathrm{N}$, over the Alpha Ridge.

The euphotic depth was two times shallower over the shelf $(34 \pm 10 \mathrm{~m})$ than over the deep basins (62 \pm 14 m; Fig. 2b) and was particularly shallow over the Chukchi Cap and Mendeleev Abyssal plain region (about $40 \mathrm{~m}$ ) while deepest $(>80 \mathrm{~m})$ in heavily sea ice covered areas. However, in sea ice covered areas where satellite data were missing, the euphotic depth was obtained by the shipside measurements, therefore light penetration does not account for the effect of the sea ice. However, our light data indicate that these sea icecovered waters were the most transparent of the cruise. 
a.

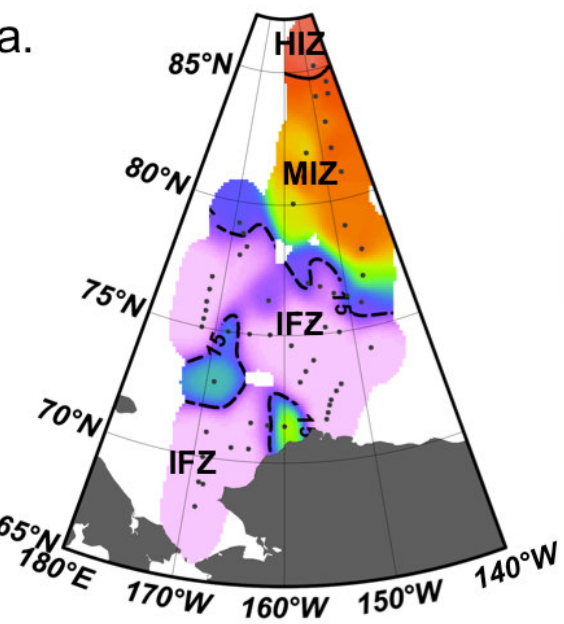

C.

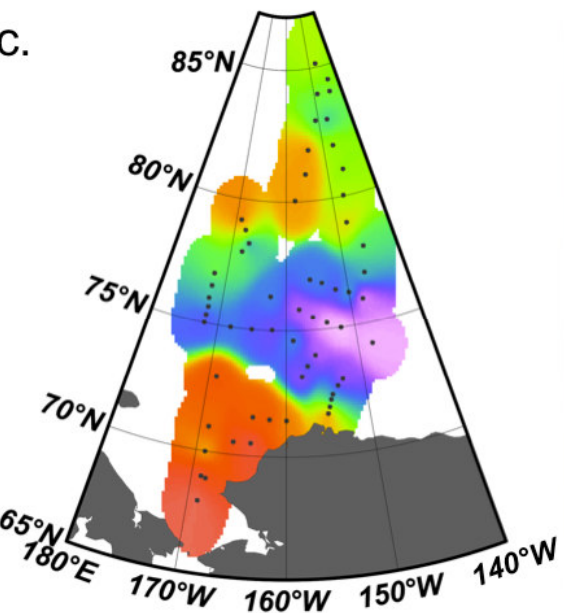

e.

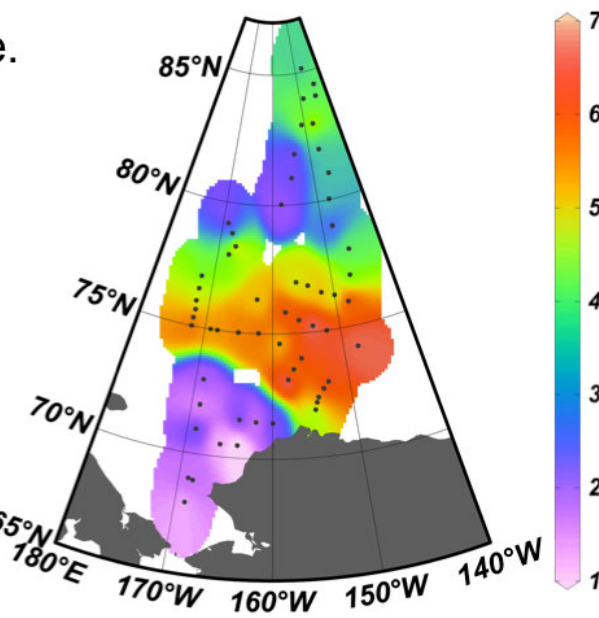

80

b.

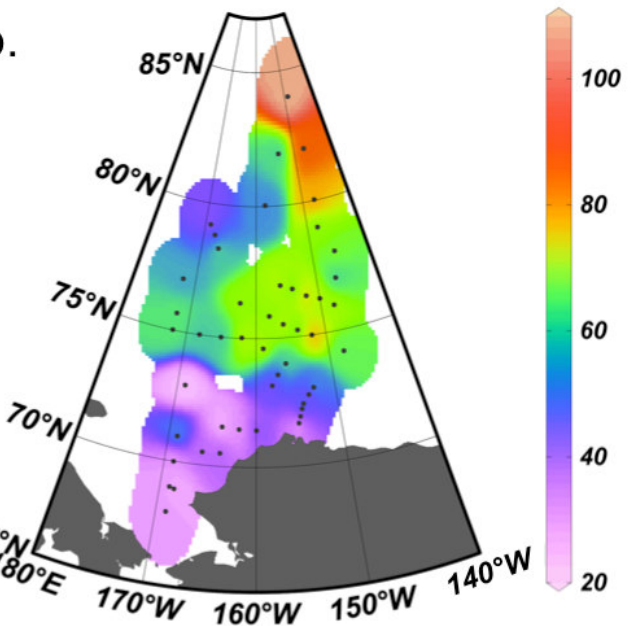

d.

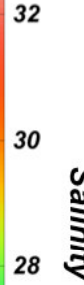

26
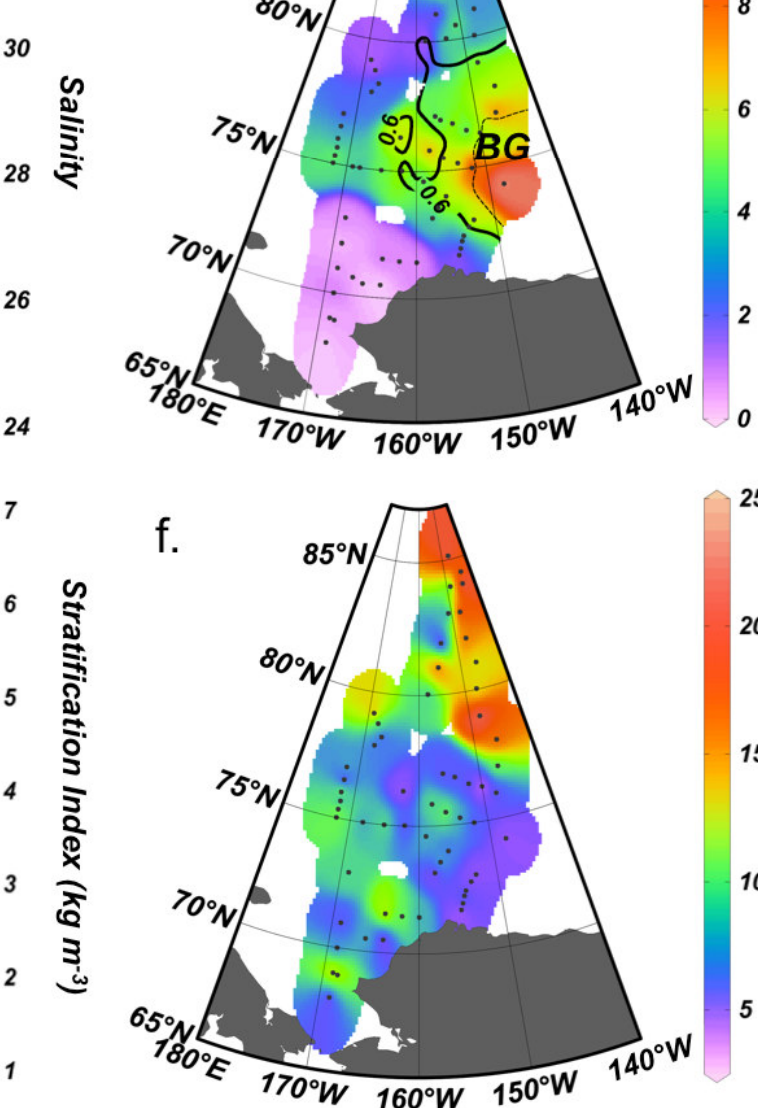

Figure 2. Environmental parameters during the CHINARE cruise in 2008. a. Co-localized sea ice concentration obtained from daily spatial sensor microwave imager data (in \%). The \% sea ice is used to distinguish between the ice-free zone (IFZ, ice < 15\%), the marginal ice zone (MIZ, 15\% < ice <80\%) and the heavy ice zone (HIZ, ice > 80\%); b. Euphotic depth (in $m$ ); c. Surface salinity; $d$. Fresh Water Content ( $F W C$ in $m$ ). The black line represents the dynamic height, indicative of the influence of the Beaufort Gyre (BG). e. Stratification index 
(in $\mathrm{kg} \mathrm{m}^{-3}$ ); f. Polar mixed layer (in $\mathrm{m}$ ).

\subsubsection{Freshening and stratification}

In 2008, the freshening and stratification were high and exhibited significant regional variability. The surface salinity was relatively high over the Chukchi shelf $(30.7 \pm 0.7$; Fig. 2c) compared to the deep basins $(26.8 \pm 1.7)$ with surface salinity 2 units lower in the ice-free basins $(26.0 \pm 1.4)$ than in the ice-covered basins. The lowest surface salinity values (24-25) were found in the southern Canada Basin strongly influenced by the Beaufort Gyre circulation.

The FWC, which provides an integrated view of the freshening, revealed a slightly different distribution than the surface salinity that reflects primarily surface freshening. The Chukchi shelf showed the lowest freshwater accumulation ( $F W C=0.4 \pm 0.3 \mathrm{~m}$; Fig. $2 \mathrm{~d}$ ). i.e. one order of magnitude lower than over the deep basins. Freshwater strongly accumulates in the center of Beaufort Gyre (FWC $=5-10 \mathrm{~m}$ ) and decreases sharply moving away from the gyre. A FWC value higher than $5 \mathrm{~m}$ was also found North of $83^{\circ} \mathrm{N}$, thus far from the Beaufort Gyre, in a region covered by sea ice. In contrast, the FWC was rather low in the Chukchi Cap region $(\mathrm{FWC}=1-2 \mathrm{~m})$.

Stratification tended to be high in areas where surface salinity was low and FWC high. Indeed, highest stratification was observed in the ice-free deep basins $\left(5.5 \pm 0.8 \mathrm{~kg} \mathrm{~m}^{-3}\right.$; Fig. $2 \mathrm{e})$ and peaked in the center of the Beaufort Gyre $\left(6-7 \mathrm{~kg} \mathrm{~m}^{-3}\right)$. In contrast, low stratification was found over the Chukchi shelf $\left(1.7 \pm 0.7 \mathrm{~kg} \mathrm{~m}^{-3}\right)$ and in the MIZ $\left(3.6 \pm 1 \mathrm{~kg} \mathrm{~m}^{-3}\right)$. The polar mixed layer was thinner than $25 \mathrm{~m}$ in the entire study area (Fig. 2f). In the ice-free zones, the mixed layer was less than $10 \mathrm{~m}$ thick. Surface mixing increased in the ice-covered deep basins and reached 20 - $25 \mathrm{~m}$ when sea ice cover was over $70 \%$.

\subsection{Water masses and nutrient content}

The thickness of the upper ocean layer affected by river discharge and sea ice melting $(\mathrm{S}<31)$ varied regionally, from several meters over the shelf to more than $50 \mathrm{~m}$ in the Beaufort Gyre (Fig. 3a). This freshwater layer exhibited a wide range of temperature from North to South $\left(-1.6\right.$ to $7^{\circ} \mathrm{C}$, Fig. $\left.3 b\right)$ and a depletion of nitrates $\left(\mathrm{NO}_{3}{ }^{-}<2 \mu \mathrm{M}\right.$, Fig. $\left.3 \mathrm{c}\right)$, silicates ( $\mathrm{Si}<5 \mu \mathrm{M}$, Fig. 3d) and phosphates $\left(\mathrm{PO}_{4}{ }^{3-}<1 \mu \mathrm{M}\right.$, not shown). 

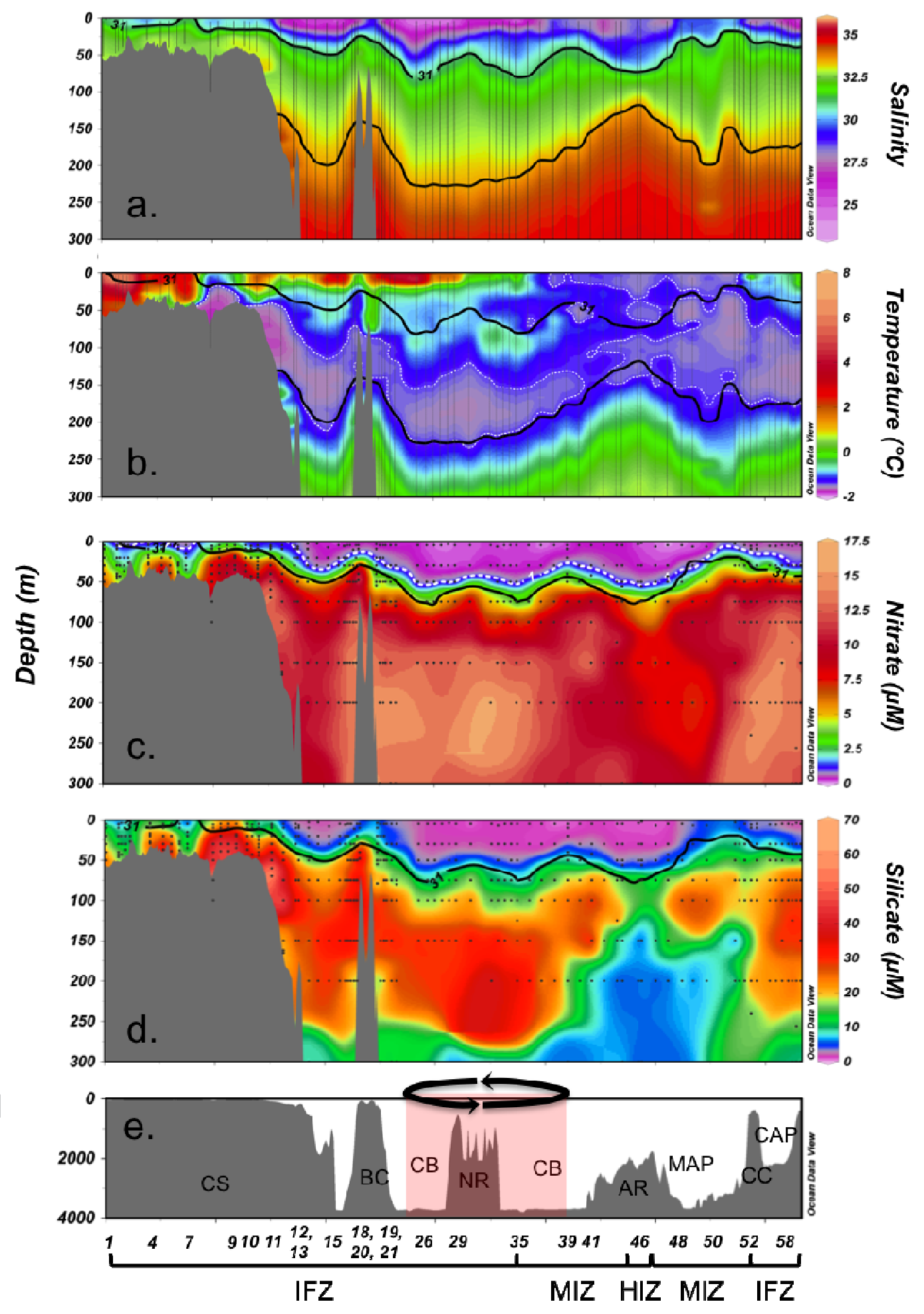

243 Figure 3. Vertical sections of the upper $300 \mathrm{~m}$ along the CHINARE 2008 ship track. The 244 station numbers indicated on the X-axis are those where primary production has been 
measured (white dots in Fig.1). a. salinity; b. temperature (in ${ }^{\circ} \mathrm{C}$ ); $c$. nitrate concentration (in $\mu M)$, the dotted white line represents the $1 \mu M$ isoline; $d$. silicate concentration (in $\mu M)$; $\boldsymbol{e}$. bathymetry (in $\mathrm{m}$ ). Waters with temperature $<-1.4^{\circ} \mathrm{C}$ (dotted white line in panel $b$ ) and salinity in the range of 31 - 33.5 (black line in panel $a$ and b) are associated with PWW. Panel e. indicate the ice conditions (IFZ: Ice free zone; MIZ: Marginal ice zone; HIZ: Heavy ice zone) and geographic locations (CS: Chukchi Shelf; BC: Barrow Canyon; CB: Canada Basin; NR: Northwind Ridge; AR: Alpha Ridge; MAP: Mendeleev Abyssal Plain; CC: Chukchi Cap; CAP: Chukchi Abyssal Plain). The black arrows and overlying red area show the region of influence of the Beaufort Gyre.

Freshwater accumulation in the upper layer created a strong salinity gradient from the bottom of the mixed layer down to $250 \mathrm{~m}$ (Fig. 3a). Nitrate concentration increase with depth to reach maximum values at the depth of the Pacific Winter Waters (PWW, $\mathrm{NO}_{3}{ }^{-}>10 \mu \mathrm{M}$, Fig. 3c). PWW are usually traced by $\mathrm{T}$ values $<-1.4^{\circ} \mathrm{C}$, (Fig. 3b), salinity values lying between 31 and 33.5 (Fig. 3a) and a silicate maximum (20-60 $\mu$ M, Fig. 3d). The nutrient pool associated with the PWW was found close to the surface over the Chukchi Shelf $(20-50 \mathrm{~m})$ and deeper over the basins (100-200 m) (Fig. 3c, 3d). The Pacific Summer Waters (PSW), characterized by $-1.0^{\circ} \mathrm{C}<\mathrm{T}<-0.5^{\circ} \mathrm{C}$ (between 50 and $100 \mathrm{~m}$; Fig. 3b), had two times lower nutrient content than the PWW. The silicate fingerprint of the PWW was observed at all stations up to $85^{\circ} \mathrm{N}$, whereas that of the PSW was only observed over the shelf and in the southern Canada Basin (Fig. 3d). Thus, during summer the upper Arctic waters were characterized by a freshwater layer depleted in nutrients, overlying the sub-surface PWW, the major nutrient source for the Arctic basin. The nutrient availability for phytoplankton thus depends on physical processes bringing PWW to the surface.

\subsection{Chlorophyll- $a$ and primary production}

\subsubsection{Chlorophyll-a concentration}

Despite a shallow euphotic depth (Fig. 2b), the Chukchi Shelf exhibited the highest phytoplankton biomasses observed during the cruise, with mean Chla concentrations of $0.88 \pm 0.76 \mathrm{mg} \mathrm{m}^{-3}$ in surface waters (Fig. $4 \mathrm{a}$ ) and $1.49 \pm 1.41 \mathrm{mg} \mathrm{m}^{-3}$ in the SCM (Fig. 4b). Chla concentration reached a maximum of $4.94 \mathrm{mg} \mathrm{m}^{-3}$ at $20 \mathrm{~m}^{\text {in }}$ the Central Canyon (Fig. 4b). Rather high values, $2.83 \mathrm{mg} \mathrm{m}^{-3}$ were also observed in surface waters, North of the Bering Strait (Fig. 4a). Lowest numbers $\left(\sim 0.2 \mathrm{mg} \mathrm{m}^{-3}\right)$ were found in shelf waters along the Alaskan coast, presumably reflecting the nutrient-depleted waters of the Alaskan Coastal Current. 
a.

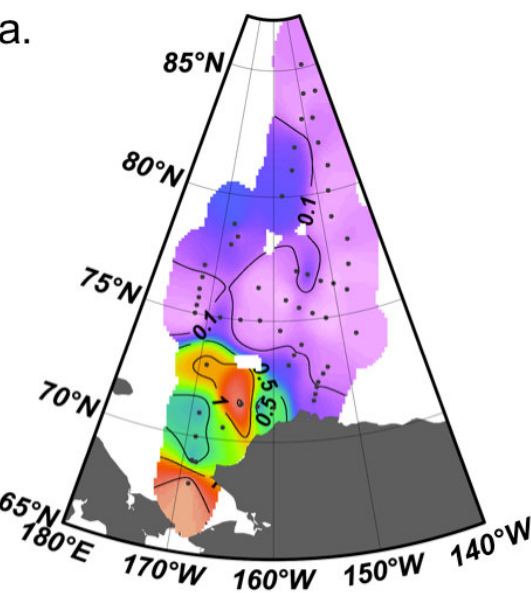

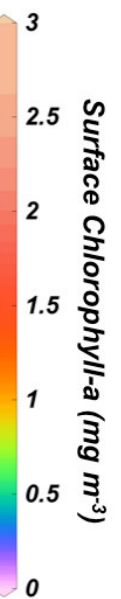

b.

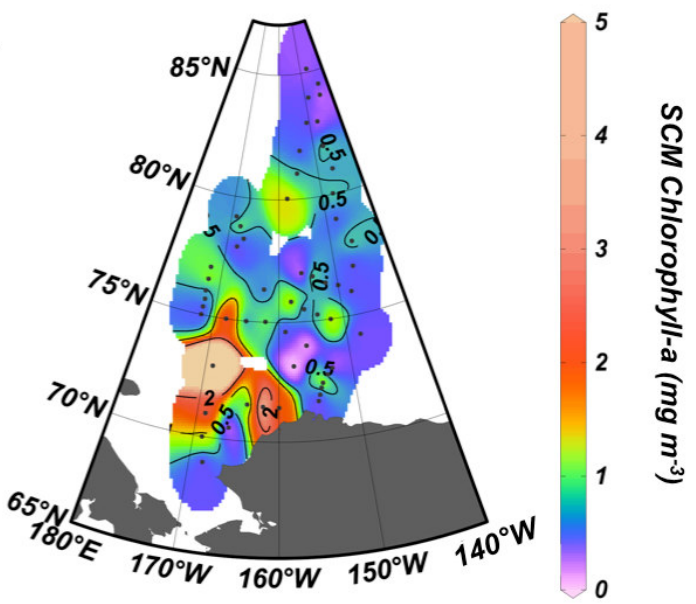

Figure 4. Chlorophyll-a concentration in $\mathrm{mg} \mathrm{m}^{-3}$ a. in Surface and $b$. in the sub-surface chlorophyll maximum (SCM).

Over the deep basins, Chla concentrations were extremely low in surface waters $\left(0.09 \pm 0.08 \mathrm{mg} \mathrm{m}^{-3}\right.$, Fig. 4a, 5a) but relatively high in the SCM $\left(0.42 \pm 0.28 \mathrm{mg} \mathrm{m}^{-3}\right.$, Fig. $4 \mathrm{~b}$, 5a) compared to mean values found in the oligotrophic subtropical gyre waters $\left(\sim 0.1 \mathrm{mg} \mathrm{m}^{-3}\right.$, (Sarmiento and Gruber, 2006)). Chla concentrations in the SCM of the basin were highly

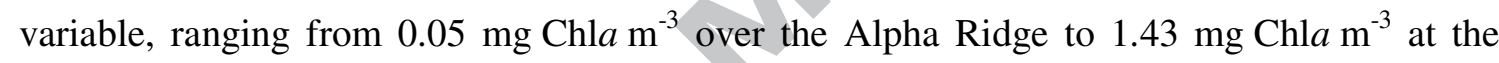
mouth of Barrow Canyon. Surface Chl $a$ at some stations of the continental slope and over the Chukchi Cap - Mendeleev Abyssal Plain region were quite remarkable with concentrations 2 to 5 times higher than found at other stations of the deep basin.

The depth of the SCM varied regionally (Fig. 5a). The SCM depth was, on average 2 times deeper over the basins $(47 \pm 17 \mathrm{~m})$ than over the Chukchi shelf $(24 \pm 8 \mathrm{~m})$. The SCM was deeper in the Canada Basin $(53 \pm 13 \mathrm{~m})$, on the northern transit in August, than in the Mendeleev Abyssal Plain, Chukchi Cap and Chukchi Abyssal Plain (38 $\pm 11 \mathrm{~m})$, occupied on the way back, in early September. The SCM was about shallower at the edge of the Beaufort Gyre than in the ice-free regions of the Canada Basin. Finally, offshore Central Canyon and Barrow Canyon the SCM was relatively deep (about $40 \mathrm{~m}$ ) with a high Chla content (>1 mg $\mathrm{m}^{-3}$ ). 

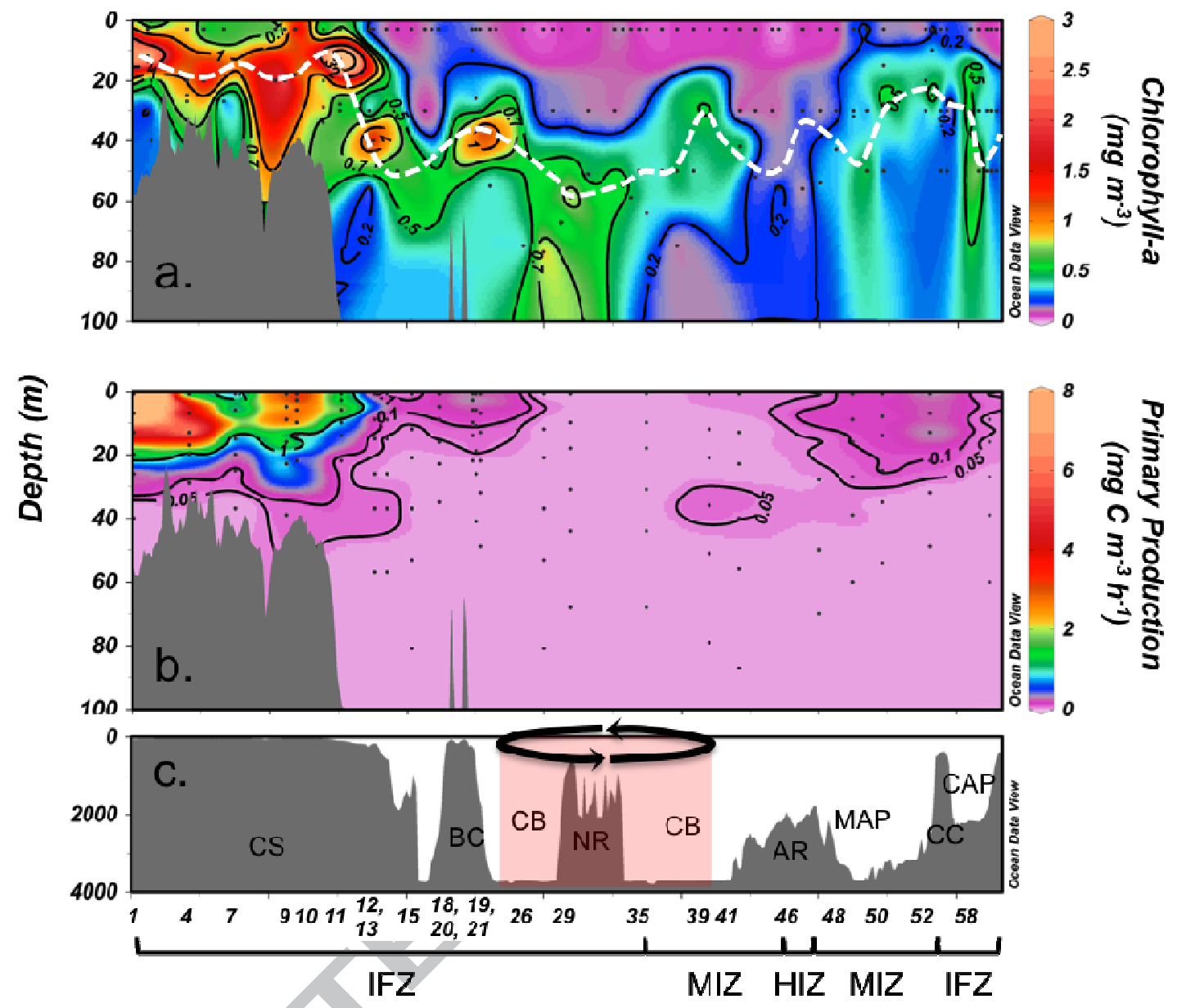

Figure 5. Vertical sections of the upper $100 \mathrm{~m}$ showing a. Chlorophyll-a (in $\left.\mathrm{mg} \mathrm{m}^{-3}\right)$ and the depth of the subsurface Chla maximum (white dashed line); $b$. Primary production ( $m g \mathrm{C} \mathrm{m}^{-3}$ $h^{-1}$ ); c. bathymetry from the surface to $4000 \mathrm{~m}$ depth (in $\mathrm{m}$ ). The stations where primary production was measured (white dots in Fig.1) are indicated on the X-axis. Panel c. gives the ice conditions (IFZ: Ice free zone; MIZ: Marginal ice zone; HIZ: Heavy ice zone) and geographic locations (CS: Chukchi Shelf; BC: Barrow Canyon; CB: Canada Basin; NR: Northwind Ridge; AR: Alpha Ridge; MAP: Mendeleev Abyssal Plain; CC: Chukchi Cap; CAP: Chukchi Abyssal Plain). The black arrows and red shaded area highlight the Beaufort Gyre.

\subsubsection{Primary production}

The highest PP levels were found in the upper $20 \mathrm{~m}$ of the Chukchi Shelf, with values ranging from $0.4 \mathrm{mg} \mathrm{C} \mathrm{m}^{-3} \mathrm{~h}^{-1}$, near the Alaskan coast, to $19.6 \mathrm{mg} \mathrm{m} \mathrm{m}^{-3} \mathrm{~h}^{-1}$, near Bering Strait, with an average value of $2.0 \pm 2.1 \mathrm{mg} \mathrm{C} \mathrm{m}^{-3} \mathrm{~h}^{-1}$ in the euphotic depth layer (Fig. 5b). Over the deep basins, PP was one to two orders of magnitude lower. The Mendeleev Abyssal Plain/Chukchi Cap and the Barrow Canyon regions had the highest PP of the deep basin $(0.2$ 
$317 \pm 0.01 \mathrm{mg} \mathrm{C} \mathrm{m}^{-3} \mathrm{~h}^{-1}$ ). In contrast, the Canada Basin and Alpha Ridge regions showed the

318 lowest PP $\left(<0.1 \mathrm{mg} \mathrm{C} \mathrm{m} \mathrm{Ch}^{-1}\right)$. Our results also show that the PP/Chla ratio decrease 319 exponentially with depth (Fig. 6a). Phytoplanktonic communities in the upper $10 \mathrm{~m}$ produce 320100 times more $\mathrm{C}$ per unit of Chl $a$, than those living at $60 \mathrm{~m}$. The highest PP/Chla ratios (1 to 321 10) were observed at the depth receiving $50 \%$ of the surface irradiance (Fig. 6b). At 5\% and $3221 \%$ of surface irradiance, productivity is 100 to 1000 times lower than at $50 \%$. Note that the $323 \mathrm{PP} / \mathrm{Chl} a$ ratios were one order of magnitude lower in surface waters $(100 \%$ of surface 324 irradiance) than at $50 \%$ irradiance depth, suggesting light inhibition of surface 325 phytoplanktonic communities.

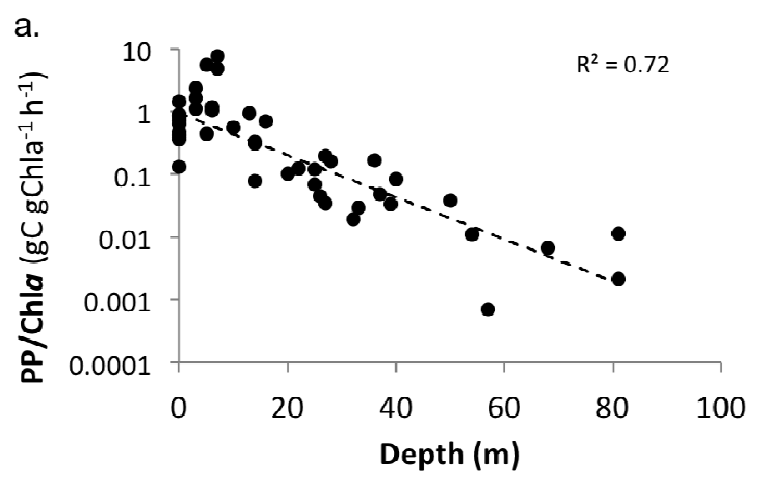

b.

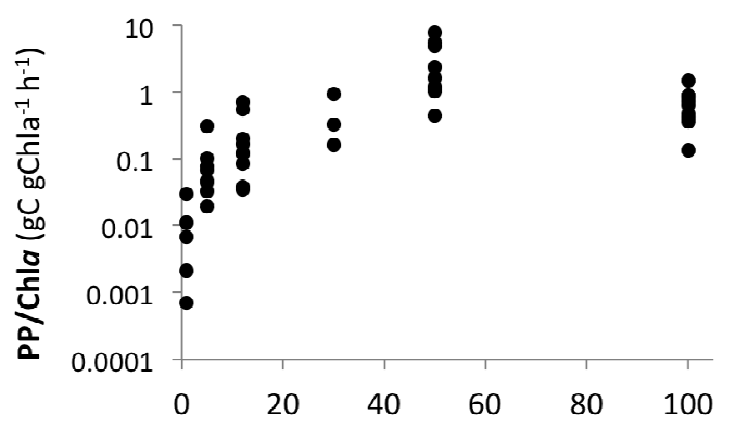
$\%$ of Surface Irradiance

Figure 6. PP/Chla ratio values plotted as a function of $\boldsymbol{a}$. depth (in $\mathrm{m}$ ) and $\boldsymbol{b}$. percentage of surface irradiance. Note that the Y-axis is in log scale.

\subsection{Principal component analysis}

Figures $7 \mathrm{a}$ and $7 \mathrm{~b}$ show the result of the PCA performed on our dataset (60 stations and 15 variables). The two first axes of the PCA explain more than $65 \%$ of the total variance (Fig. 7a). Bathymetry, FWC, PWW depth, nitracline, nitrate concentration, stratification, euphotic depth and dynamic height are the main variables responsible for the construction of PC1 whereas temperature, sea ice concentration and polar mixed layer primarily account for the 
construction of PC2 (Fig. 7b). The PCA results also reveal that the bathymetry, FWC, euphotic depth (Zeu), nitracline depth, PWW depth, the dynamic height and stratification index were positively correlated $\left(\mathrm{PC}^{-}\right)$while these variables were negatively correlated with nitrate concentrations $\left(\mathrm{PC}^{+}\right)$. The $\mathrm{PC} 2$ shows that the surface temperature $\left(\mathrm{PC}^{+}\right)$was negatively correlated with the sea ice concentration and the PML depth (PC2-). Moreover, the PCA indicates that temperature, sea ice concentration and polar mixed layer depth were independent of the variables linked to PC1. The over plot of biological parameters (PP, Chla surf, Chla SCM, SCM depth) added as supplementary variables, suggest that higher PP and Chl $a$ concentrations are associated with shallower SCM. Biological variables do not seem to be influenced by variables accounting for PC2.

These results underline the correlations between FWC and PWW depth (Fig 7c), the FCW and the nitracline and SCM depth (Fig 7d), and between the FCW and stratification index (Fig $7 \mathrm{e})$.

b.
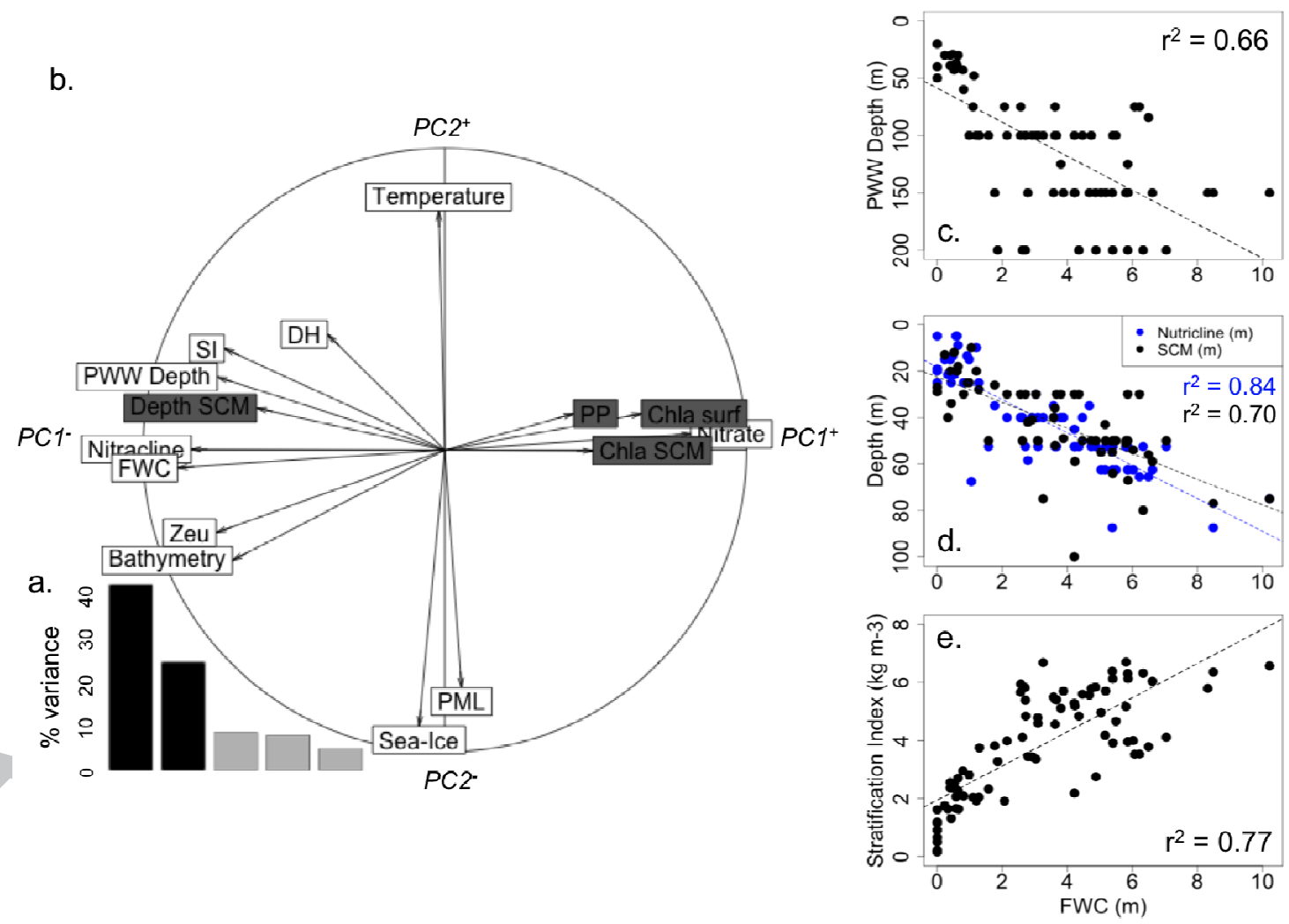

Figure 7: Results of the Principal component analysis (PCA) of the CHINARE 2008 dataset a. Percentage of explained variance of each of the five first PC axes. Black bars indicate the variance explained by the two first axis; $b$. PCA factor loadings plot; White labels correspond to active variables in the calculations, while dark grey labels are the added biological variables, not used for the calculations. PML: Polar Mixed Layer; Sea-Ice: sea ice cover; 
FWC: Fresh Water Content; Zeu: euphotic zone depth; DH: Dynamic Height; PWW depth: depth of the Pacific Winter Water; SI: stratification index; Nitracline: depth of the nitracline; Bathymetry: bottom depth; Nitrate: mean nitrate concentration over the euphotic depth; Depth SCM: depth of the sub-surface chlorophyll maximum; Chla surf: chlorophyll-a concentration in surface waters; Chla SCM: chlorophyll-a concentration in the sub-surface chlorophyll maximum; PP: Primary Production integrated over the euphotic depth; $c$. FWC versus $P W W$ depths; $d$. FWC versus the nitracline depths (blue dots) and FWC versus SCM depths (black dots); e. FWC versus SI. The determination coefficient corresponding to the linear fit of each sub-dataset is also shown.

\section{Discussion}

\subsection{The freshening as a control of the nutrient availability}

The multivariate method PCA is used here to discuss the relationship between variables presumably important to phytoplankton production. As can be seen from Figure $7 \mathrm{~b}, \mathrm{PP}$ and Chla concentrations were not directly affected by either sea ice concentration or the temperature and depth of the mixed layer, as reflected by the orthogonal direction of PC1 and PC2. This supports the idea that phytoplankton was not light-limited in summer 2008 in contrast to icy years when offshore phytoplankton was restrained by a shallow light penetration (Gosselin et al., 1997; Hill and Cota, 2005). We observed than most of the Pacific sector of the Arctic Ocean was free of ice and that the euphotic depth was deeper than the mixed layer. Satellite data indicate that 2008 was the year of minimum multiyear ice coverage on record (Maslanik et al., 2011) in agreement with in situ sea-ice observations during the cruise showing prevailing first-year ice and the omnipresence of melt ponds (Lu et al., 2010). Given that first-year sea ice transmits 3-fold more light than multiyear sea ice (Frey et al., 2011; Nicolaus et al., 2012), it is likely that the light penetration was also high in waters covered by sea ice (MIZ and HIZ). The high transparency of sea ice covered waters (Fig. 2b) may have favored light transmission in the water column.

The PCA shows that the highest PP and Chla concentrations were related to high nitrate concentrations and a shallow nitracline. This relationship highlights that under reduced sea ice cover, PP would be primarily controlled by nutrient availability in the euphotic layer as reported by several studies (Tremblay and Gagnon, 2009; Tremblay et al., 2002; Tremblay et al., 2006). The nutrient-rich regions with high PP and Chla were observed at low FWC, weak stratification, deep PWW and both shallow euphotic layer and bathymetry. In contrast, nutrient-poor regions with low PP and Chla were associated with high FWC, strong stratification, shallow PWW and both deep euphotic layer and bathymetry. We suggest that a high FWC, resulting from increased thickness of the freshwater surface layer, deepened the sub-surface nutrients reservoir of PWW (Fig. 7c) and strengthened stratification (Fig. 7e). 
Such stratified conditions then reduce vertical mixing and subsequently the renewal of nutrients from PWW. Consequently, regions with high FWC exhibit stronger surface water nitrate depletion and a deeper nitracline and SCM (Fig. 7d). Moreover, the nitrate depletion of the surface layer may be enhanced by the low nutrient content of sea-ice meltwater. Melnikov et al. (2002) reported mean summer silicate and phosphate concentrations in sea ice that are below 1 and $0.5 \mu \mathrm{M}$, respectively. The observed impact of freshening on the nitracline and SCM depth is consistent with earlier observations in the Canada Basin, between 2002 and 2009, and confirm the effect of freshening on PP and Chla, as hypothesized by McLaughlin and Carmack (2010).

The negative impact of FWC on primary production appeared to be linked to the influence of the nitracline depth on the SCM. Despite relatively high Chla concentrations, deep SCM exhibit very low rates of carbon fixation as shown by the exponential decrease of the PP/Chla ratio with depth (Fig. 6a). In fact, the deep communities under light-limited conditions need to produce more Chla to absorb light. This is illustrated by the depth difference between the SCM and PP maximum. The more productive stations (Fig. 8d) had shallow nitraclines (Fig. 8b) and SCM depths close or associated with the PP maximum (Fig. 8c). Conversely, poorly productive stations coincide with a deep nitracline and much deeper SCMs than the PP maximum. This was particularly true for the southern Canada Basin where, due to the influence of the Beaufort Gyre on nitracline depth, the SCM was deeper than $60 \mathrm{~m}$ while maximum PP was found at approximately $15 \mathrm{~m}$. 
a.

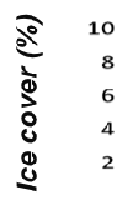

b.

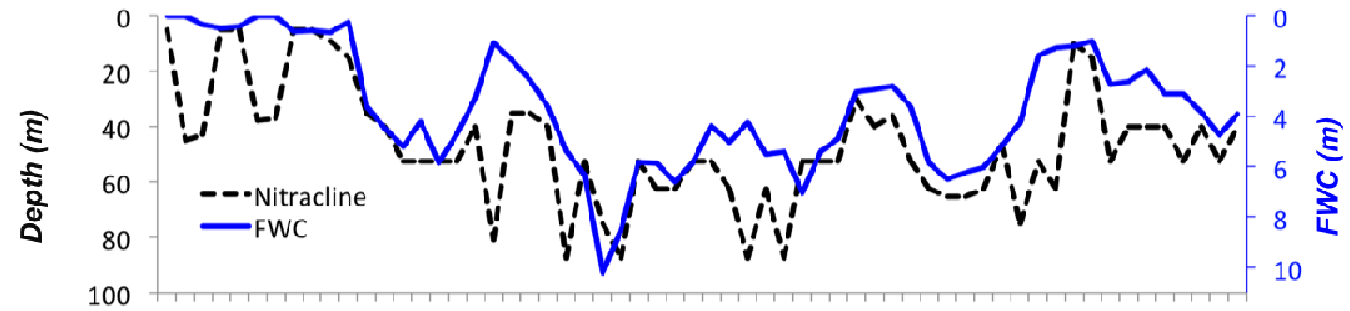

C.

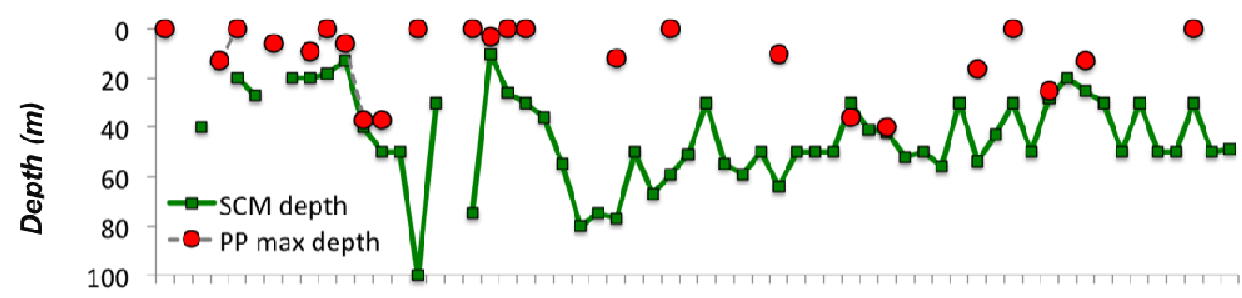

d.

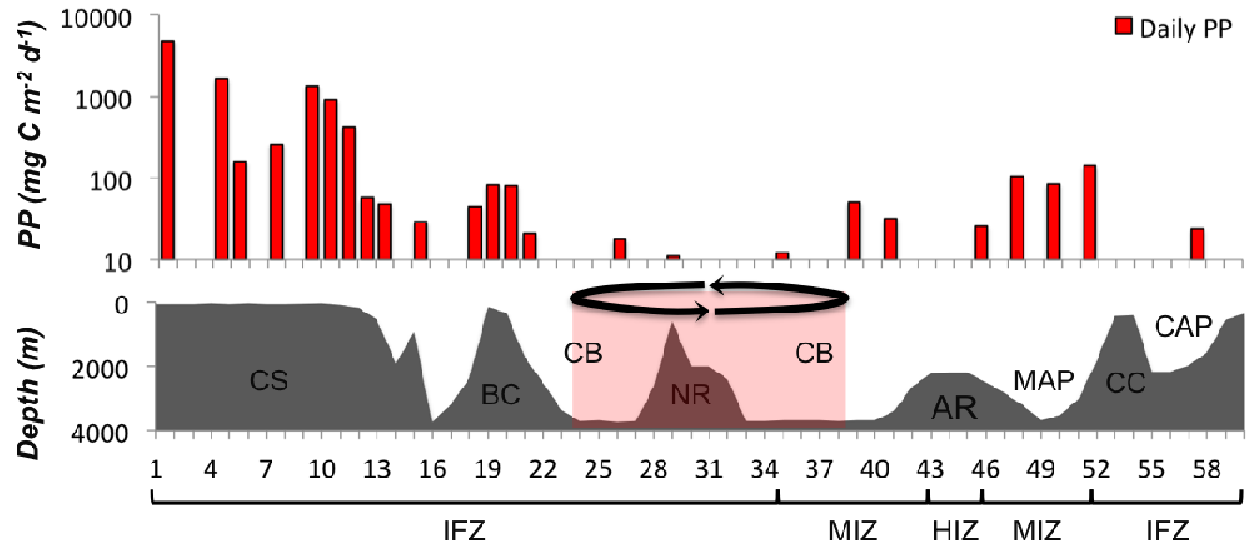

Figure 8. Environmental and biological parameters from the different provinces measured at the 60 stations of the CHINARE 2008 cruise (Fig. 1). a. Ice cover (\%) measured the day of sampling, $D$ (grey thick line) and 7 days prior to sampling, D-7 (grey dashed line); $b$. Depth of the nitracline (in $m$ ) (black dashed line) and of the Fresh Water Content (in m) (FWC, blue line); c. Depth of the chlorophyll maximum (in $m$ ) (SCM, green line) and of the maximum PP rates (red dots); $d$. Daily primary production integrated over the euphotic depth (PP in $\mathrm{mg} C$ $m^{-2} d^{-1}$ ); e. Bathymetry (in $m$ ) with the ice conditions (IFZ: Ice free zone; MIZ: Marginal ice zone; HIZ: Heavy ice zone) and geographic locations, CS: Chukchi Shelf; BC: Barrow Canyon; CB: Canada Basin; NR: Northwind Ridge; AR: Alpha Ridge; MAP: Mendeleev Abyssal Plain; CC: Chukchi Cap; CAP: Chukchi Abyssal Plain. The black arrows and overlying red area show the region influenced by the Beaufort Gyre.

\subsection{Freshwater drives the regional productivity}

Since freshening appears to be a controlling factor of nutrient availability, PP and Chla concentrations, its spatial distribution and regional impact were investigated across the study 
area. Although the FWC distribution is thought to reflect sea ice cover and melting, high FWC was found in heavily ice-covered regions, and lower FWC in the ice-free Chukchi shelf (Fig. 8a, 8b). In fact, a large fraction of the freshwater input to the upper Arctic Ocean is of riverine origin (Jones et al., 2008). This amount of freshwater is redistributed by the ocean circulation (i.e. the Pacific inflow, the Beaufort Gyre spin up and the transpolar drift) leading to regional differences of the FWC depth (Giles et al., 2012; Morison et al., 2012). In the following, we investigate regional causes of FWC and its impact on primary producers.

\subsubsection{Intense freshening in the ice-free basins reinforces oligotrophy}

The ice-free southern Canada Basin was the region most affected by freshening due to influenced of the Beaufort Gyre circulation. Stronger freshening led to thinnest mixed layer $(<$ $10 \mathrm{~m}$ ), strongest stratification $\left(>5 \mathrm{~kg} \mathrm{~m}^{-3}\right.$ ) and deepest PWW nutrient pool (about $150 \mathrm{~m}$, Table 1). The Beaufort Gyre region was characterized by a marked nitrate depletion down to $60 \mathrm{~m}$ (Fig. 3c, 3d) and a deep SCM (59 $\pm 16 \mathrm{~m}$ ) (Fig. 8c). The very low PP/Chl $a$ ratios at the $\operatorname{SCM}\left(0.01 \pm 0.01 \mathrm{~g} \mathrm{C} \mathrm{gChl} a^{-1} \mathrm{~h}^{-1}\right.$, Table 1$)$ point out slow-growing communities and their adaptation to reduced light intensity rather than active production of carbon biomass. The integrated PP values over the ice-free Canada Basin $\left(24 \pm 15 \mathrm{mg} \mathrm{C} \mathrm{m}^{-2} \mathrm{~d}^{-1}\right.$, Table 1) were 3 to 5 times lower than those found in the same area in August 1993, when the region was covered by sea-ice and less affected by freshening (123 $\mathrm{mg} \mathrm{C} \mathrm{m}^{-2} \mathrm{~d}^{-1}$ (Cota et al., 1996)) or in July 2005 (60 $\mathrm{mg} \mathrm{C} \mathrm{m}^{-2} \mathrm{~d}^{-1}$ (Lee et al., 2010)). These features may, in part, also reflect seasonal effects. Indeed, the earlier sea-ice retreat in recent years could explain earlier nutrient depletion and subsequent lower primary production rates at this time of the year.

The ice-free Chukchi Abyssal Plain was also associated with a strong stratification and weak vertical mixing driving low surface water Chla concentration $\left(0.09 \pm 0.07 \mathrm{mg} \mathrm{Chl} a \mathrm{~m}^{-3}\right.$, Table 1). The weaker influence of the Beaufort Gyre was likely responsible for lower FWC $(3.2 \pm 0.8 \mathrm{~m})$ and a $15 \mathrm{~m}$ shallower nitracline and SCM than found in the southern Canada Basin. However, the Chukchi Abyssal Plain waters were sampled 2 weeks after those of the Canada Basin, allowing for more nutrient consumption by phytoplankton. The PP values in this area (24 $\left.\mathrm{mg} \mathrm{C} \mathrm{m}^{-2} \mathrm{~d}^{-1}\right)$ were similar as those of the ice-free Canada Basin but the PP/Chla ratio was slightly higher, emphasizing better carbon fixation efficiency by primary producers. The large dominance of nanoplankton in these two poorly-productive ice-free basins (Coupel et al., 2012) support earlier observations of Li et al. (2009) showing that small cell algae flourish as the Arctic Ocean freshens. 
Table 1: The mean values of physical and biogeochemical parameters are presented for the stations located over the shelf (depth $<100 \mathrm{~m})$ and over deep basisn (depth $>100 \mathrm{~m}$ ). Subprovinces of the basin are clustered according to geographical location and sea-ice conditions, i.e. the ice-free zone (IFZ, ice < 15\%); the marginal ice zone (MIZ, $15 \%<$ ice $<80 \%$ ) and the heavy ice zone (HIZ, ice > 80\%). The Chukchi Shelf, Canada Basin and Alpha Ridge were visited in August 2008 while the Chukchi Abyssal Plain, the Chukchi Cap (CC) and the Mendeleev Abyssal Plain (MAP) were visited during the way back, in September. FWC: Freshwater Content; SI: Stratification Index; the Pacific Winter Water $(P W W)$ depth is determined with three criteria: $T<-0.5^{\circ} \mathrm{C} ; 31<S<33.5 ; P P_{e u}$ is the daily primary production integrated over the euphotic depth. The ratio PP/Chla is given for surface waters and subsurface Chlorophyll a maximum (SCM).

\begin{tabular}{|c|c|c|c|c|c|c|c|c|c|c|c|}
\hline & \multirow[t]{2}{*}{$\begin{array}{l}\text { Ice cover } \\
(\%)\end{array}$} & \multirow[t]{2}{*}{ FWC (m) } & \multirow[t]{2}{*}{$\begin{array}{c}\mathrm{SI} \\
\left(\mathrm{kg} \mathrm{m}^{-3}\right)\end{array}$} & \multirow{2}{*}{$\begin{array}{l}\text { PWW } \\
\text { depth } \\
(m)\end{array}$} & \multirow[t]{2}{*}{$\begin{array}{l}\text { Nitracline } \\
\text { (m) }\end{array}$} & \multirow{2}{*}{$\begin{array}{c}\text { SCM } \\
\text { depth } \\
\text { (m) }\end{array}$} & \multicolumn{2}{|c|}{$\begin{array}{l}\text { Chlorophyll } a \\
\left(\mathrm{mg} \mathrm{m}^{-3}\right)\end{array}$} & \multicolumn{3}{|c|}{$\begin{array}{cc}\mathrm{PP}_{\mathrm{eu}} & \mathrm{PP} / \mathrm{Chla} \\
\left(\mathrm{mg} \mathrm{C} \mathrm{m}^{-2} \mathrm{~d}^{-1}\right) & \left(\mathrm{gC} \mathrm{gChla}^{-1} \mathrm{~h}^{-1}\right)\end{array}$} \\
\hline & & & & & & & Surface & SCM & 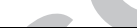 & Surface & SCM \\
\hline $\begin{array}{l}\text { SHELF }(\mathbf{n}=11) \\
(z<100 \mathrm{~m})\end{array}$ & $6 \pm 15$ & $0.4 \pm 0.3$ & $1.7 \pm 0.6$ & $39 \pm 11$ & $22 \pm 15$ & $24 \pm 8$ & $0.88 \pm 0.76$ & $1.49 \pm 1.41$ & $1380 \pm 1628$ & $3.6 \pm 2.7$ & $0.2 \pm 0.2$ \\
\hline $\begin{array}{l}\text { BASIN }(n=49) \\
(z>100 m)\end{array}$ & $22 \pm 31$ & $4.3 \pm 2.0$ & $4.4 \pm 1.9$ & $134 \pm 39$ & $53 \pm 17$ & $47 \pm 17$ & $0.09 \pm 0.08$ & $0.45 \pm 0.34$ & $51 \pm 37$ & $0.8 \pm 0.5$ & $0.06 \pm 0.06$ \\
\hline $\begin{array}{l}\text { IFZ }\left(74-78^{\circ} \mathrm{N}\right) \\
\text { (Canada Basin) }\end{array}$ & $2 \pm 5$ & $5.5 \pm 1.8$ & $5.9 \pm 0.6$ & $150 \pm 30$ & $59 \pm 16$ & $55 \pm 17$ & $0.08 \pm 0.07$ & $0.47 \pm 0.39$ & $24 \pm 15$ & $0.6 \pm 0.2$ & $0.01 \pm 0.01$ \\
\hline $\begin{array}{l}\text { IFZ }\left(75-78^{\circ} \mathrm{N}\right) \\
\text { (Chukchi } \\
\text { Abyssal Plain) }\end{array}$ & $0 \pm 0$ & $3.2 \pm 0.8$ & $4.9 \pm 0.7$ & $134 \pm 44$ & $45 \pm 6$ & $42 \pm 10$ & $0.09 \pm 0.07$ & $0.44 \pm 0.23$ & 24 & 0.8 & 0.03 \\
\hline $\begin{array}{l}\text { MIZ }\left(78-83^{\circ} \mathrm{N}\right) \\
\text { (Canada Basin) }\end{array}$ & $56 \pm 23$ & $4.5 \pm 1.5$ & $4.0 \pm 1.0$ & $136 \pm 52$ & $52 \pm 17$ & $48 \pm 9$ & $0.05 \pm 0.03$ & $0.39 \pm 0.15$ & $32 \pm 19$ & $0.5 \pm 0.2$ & $0.08 \pm 0.08$ \\
\hline $\begin{array}{l}\text { MIZ }\left(78-83^{\circ} \mathrm{N}\right) \\
(\mathrm{CC}+\mathrm{MAP})\end{array}$ & $46 \pm 24$ & $2.4 \pm 1.8$ & $2.6 \pm 0.8$ & $100 \pm 0$ & $43 \pm 26$ & 1 & $0.20 \pm 0.11$ & $0.55 \pm 0.28$ & $111 \pm 29$ & $0.7 \pm 0.3$ & $0.15 \pm 0.04$ \\
\hline $\begin{array}{l}\text { HIZ }\left(83-86^{\circ} \mathrm{N}\right) \\
\text { (Alpha Ridge) }\end{array}$ & $78 \pm 8$ & $6.1 \pm 0.3$ & $3.8 \pm 0.2$ & $95 \pm 27$ & $64 \pm 2$ & $47 \pm 12$ & $0.05 \pm 0.01$ & $0.22 \pm 0.11$ & 26 & 0.4 & 0.02 \\
\hline
\end{tabular}

\subsubsection{Heavily ice-covered basins also affected by freshening}

High freshening was also observed in the heavily ice covered Alpha Ridge zone (HIZ, Table 1). Freshwater at such high latitudes result from sea-ice meltwater and water discharges from the Siberian Rivers as previously reported (Johnson and Polyakov, 2001; Jones et al., 2008; Semiletov et al., 2000; Serreze et al., 2006). Enhanced freshening is associated with a nutrient depleted layer as deep as $64 \pm 2 \mathrm{~m}$. However, it is difficult to disentangle the effect of freshening and phytoplankton consumption. Considering the high transparency of the waters (Fig. 2b) and the presence of first-year ice and melt ponds (Lu et al., 2010), nutrients may have been consumed by phytoplankton as deep as $64 \mathrm{~m}$. Although biomasses are very low at

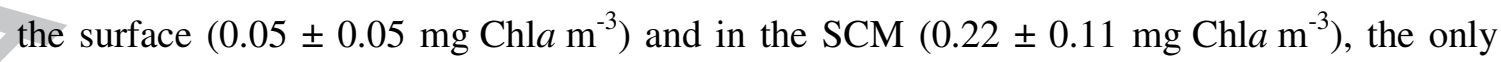
available integrated PP at these high latitudes $\left(26 \mathrm{mg} \mathrm{C} \mathrm{m}^{-2} \mathrm{~d}^{-1}\right)$ indicate values close to those found in the ice-free basins. Note that sea ice algae were not considered and therefore primary production is likely be underestimated. Nevertheless, nutrient depletion at such high latitudes could also be a permanent feature due to low mixing rates, amplified by summer freshening. Another possible explanation for low primary production, is the limited northern expansion of nutrient-rich PWW over the Alpha Ridge zone, resulting in 3 times lower silicate and nitrate 
concentrations in the subsurface layer than found in the southern basin (Fig. 3c, 3d).

\subsubsection{Enhanced productivity in regions with low freshening}

The highest PP values in the deep basins $\left(111 \pm 29 \mathrm{mg} \mathrm{C} \mathrm{m}^{-2} \mathrm{~d}^{-1}\right)$ were found in the MIZ over the Mendeleev Abyssal Plain characterized by the lowest FWC. At these stations, surface and SCM Chla were highest (Table 1). The SCM were relatively shallow and occurred at the same depth than PP maxima (Fig. 8c). The phytoplankton in the SCM was 20 times more efficient in carbon fixation (PP/Chl $\left.a=0.15 \pm 0.04 \mathrm{gC} \mathrm{gChl}^{-1} \mathrm{~h}^{-1}\right)$ than in the icefree and heavy ice-covered regions. High abundances of penate diatoms Niztchia sp. and Fragilariopsis sp. in this area (Coupel et al., 2012) indicate that new production was stimulated by high light and nutrient availability.

Lower freshening in the MIZ could result from the interaction between wind and iceedge, promoting vertical mixing and upwelling of nutrient-rich deep waters (Mundy et al., 2009; Tremblay and Gagnon, 2009; Tremblay et al., 2011), and a weak stratification (Fig. 2e, Table 1). In addition, the sea ice data show that the Mendeleev Abyssal Plain experienced a $50 \%$ decrease in sea ice cover during the preceding week (ice D-7 in Fig. 8a), allowing for increasing light penetration and phytoplankton to reach a "new" pool of nutrients. Enrichment in the MIZ is usually observed over the continental shelf but can extend over the deep basins as sea ice melting proceeds during the summer season. However, production and biomass in the offshore MIZ remained one order of magnitude lower than typical spring ice edge blooms over the Arctic shelves (Niebauer and Alexander, 1985).

Enhanced PP was less clear in the MIZ of the Canada Basin, with values 3 times lower than in the MIZ of the Mendeleev Abyssal Plain. The higher initial FWC and deeper PWW nutrient reservoir caused by the Beaufort Gyre circulation could explain the lower phytoplankton growth in the MIZ of the Canada Basin. Although reduced vertical mixing could have prevented replenishment from the deeper nutrient reservoir, we cannot rule out earlier nutrient consumption by phytoplankton. Indeed, two weeks prior the station occupation, sea ice had receded in the MIZ of the Canada Basin providing favorable conditions for phytoplankton growth. Nevertheless, we found relatively high PP values at stations $39\left(32 \mathrm{mg} \mathrm{C} \mathrm{m}^{-2} \mathrm{~d}^{-1}\right)$ and $41\left(51 \mathrm{mg} \mathrm{C} \mathrm{m}^{-2} \mathrm{~d}^{-1}\right)$, while sea ice cover was on the order of $60 \%$ (Fig. 8d). Owing to their position at the edge of the Beaufort Gyre, FWC was lower at the northern sites than in the southern Canada Basin. Lower FWC was associated with a shallower nitracline and SCM (Fig 8b), the latter coinciding with the PP maximum depth (Fig. 8c). Our results also indicate that phytoplanktonic communities in the SCM were as efficient to fix carbon (PP/Chl $\left.a=0.12 \pm 0.06 \mathrm{gC} \mathrm{gChl} a^{-1} \mathrm{~h}^{-1}\right)$ as those of the MIZ over the Mendeleev 
Abyssal Plain.

\subsubsection{A productive shelf weakly affected by the freshening}

The FWC was generally low over the shelf, presumably, because of the short residence time of shelf waters (Weingartner et al., 2005; Woodgate et al., 2005). Low FWC and weak stratification favor the replenishment of nutrients from the deeper water layer and surface sediments. The Pacific waters entering through Bering strait is another source of nutrient supply (Sambrotto et al., 1984; Springer and McRoy, 1993). The high PP and biomass of surface waters in the southern Chukchi shelf support the hypothesis of a nutrient supply from Bering Strait even in late summer. While highest PP values were found in the southern shelf waters, highest biomasses were encountered in the SCM of the northern shelf waters (close to

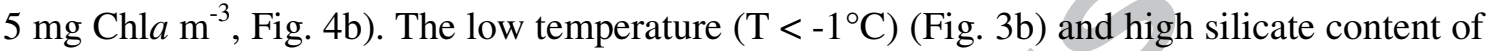
the surface waters of the northern shelf $(\mathrm{Si}>50 \mu \mathrm{M})$ (Fig. 3d) suggest that biomass production could have been promoted by upwelling cells due to the retreat of the ice cover from $80 \%$ to less than $20 \%$ in one week (Fig. 8a). Biomasses and integrated PP over the Chukchi shelf in $2008\left(1469 \pm 2040 \mathrm{mg} \mathrm{C} \mathrm{m}^{-2} \mathrm{~d}^{-1}\right.$, Table 1) were within the range of previous summer season data over the Chukchi shelf (170-1940 mg C m${ }^{-2} \mathrm{~d}^{-1}$ (Hameedi, 1978); 500$4700 \mathrm{mg} \mathrm{C} \mathrm{m} \mathrm{d}^{-1}$ (Springer and McRoy, 1993); $750 \mathrm{mg} \mathrm{C} \mathrm{m}^{-2} \mathrm{~d}^{-1}$ (Cota et al., 1996); $2570 \mathrm{mg} \mathrm{C} \mathrm{m} \mathrm{d}^{-1}$, (Gosselin et al., 1997); $780 \mathrm{mg} \mathrm{C} \mathrm{m}^{-2} \mathrm{~d}^{-1}$, (Hill and Cota, 2005); $1000 \mathrm{mg}$ $\mathrm{C} \mathrm{m}^{-2} \mathrm{~d}^{-1}$, (Tremblay et al., 2012)). These values were also close to those reported in the MIZ of the central Barents Sea (500-1400 mg C m${ }^{-2} \mathrm{~d}^{-1}$ (Reigstad et al., 2002)). The fact that our data are within the range of previous observations indicates that the recent freshening of the Arctic Ocean does not significantly affect the Chukchi shelf water primary production. Nevertheless, the comparison with earlier studies should be considered with caution because of the high spatial and temporal variability of primary production in the region, the difference in sampling period and changes in the phenology of Arctic ecosystems (Melnikov and Kolosova, 2001).

\subsection{Towards an increase or decrease of primary production in Arctic?}

Our results reveal that phytoplankton biomass and primary production in summer were primarily controlled by freshening and sea ice conditions. While sea ice can stimulates phytoplankton growth by modifying light availability, freshening acts on the nutrient reservoir and its replenishment from deeper waters. The combined effect of sea ice and freshening on the nutrient availability and primary producers is conceptualized in Figure 9. 


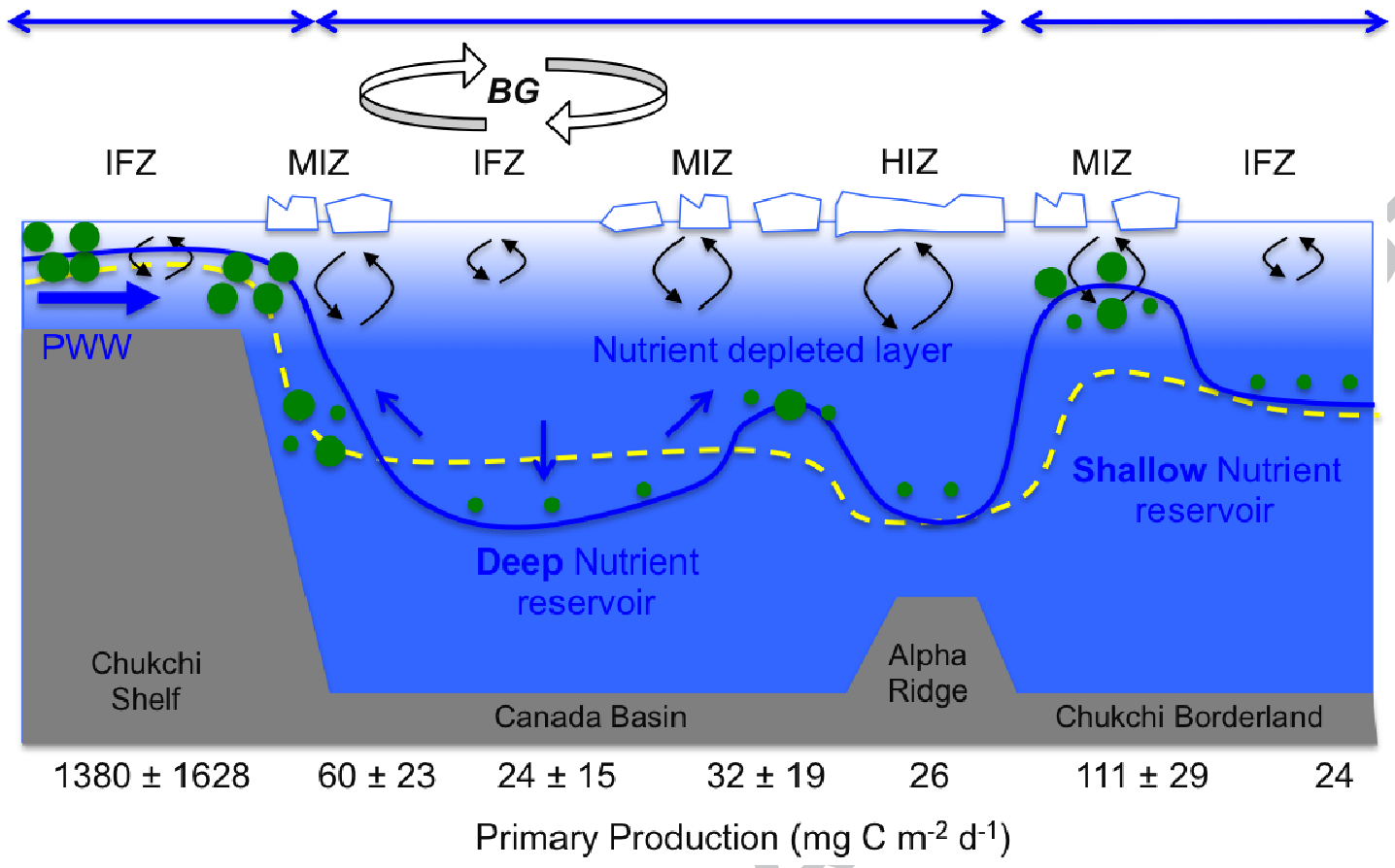

Figure 9: Conceptual model showing the nutrient and light availability in regions differently affected by sea-ice (IFZ, MIZ and HIZ), the freshening of the upper layer (Low and High) and the Beaufort Gyre circulation (BG). The blue line represents the nitracline that distinguishes the nutrient-depleted upper layer, from the subsurface Pacific Winter Water (PWW) nutrient reservoir. The dashed yellow line indicates the euphotic zone depth. The green dots sketch the phytoplankton biomass. The black arrows are indicative of surface mixing. Integrated primary production $(P P)$ mean values $\left(m g C m^{-2} d^{-1}\right)$ are given for each oceanographic provinces at the bottom of the figure.

High FWC depicts conditions encountered in the Canada Basin, while low FWC were observed over the Chukchi Borderland (Chukchi Abyssal Plain, Chukchi Cap and Mendeleev Abyssal Plain) and Chukchi Shelf. In the low freshening scenario, sea ice retreat over the deep basins is prone to create « hot spots » because of a shallower nutrient reservoir and a weaker stratification. These « hot spots » for primary production in the summer of 2008 occurred mainly in the MIZ over the Chukchi Borderland, with a mean integrated daily PP value (111 \pm $29 \mathrm{mg} \mathrm{C} \mathrm{m}^{-2} \mathrm{~d}^{-1}$ ) that was larger than those observed in August 1994 in the same area under heavily ice-covered (9-73 $\mathrm{mg} \mathrm{C} \mathrm{m}^{-2} \mathrm{~d}^{-1}$ (Gosselin et al. 1997)). In contrast, in the Canada Basin, where freshening was high and largely due to the Beaufort Gyre, phytoplankton growth in the MIZ was four times weaker. Because of a deeper nutrient reservoir and a stronger stratification, more energy is required to bring deep nutrients to the surface.

Under ice-free conditions, wind forcing can promote the deepening of the mixed layer and 
therefore nutrient repletion of the upper layer (Rainville et al., 2011). Longer ice-free conditions during autumn also contribute to favor vertical mixing by winds. Yet, ice-free basins were most strongly nutrient depleted. Stronger winds will thus be needed for deeper nutrient-rich layer to replenish surface waters. Nutrient depletion reached deeper layers in the ice-free Canada Basin than in the ice-free Chukchi Abyssal Plain because of higher freshening. Consequently, phytoplankton communities developed deeper in the ice-free Canada basin and displayed lowest carbon production values because of nutrient limitations. In the context of global warming, ice melting and freshening of the Arctic Ocean is predicted to intensify in the future (Peterson et al., 2006; Yamamoto-Kawai et al., 2009). The subsequent environment changes in this polar region are likely to have strong implication on the marine ecosystem, in particular in the deep basins.

\section{Conclusion}

Primary production and chlorophyll-a vertical distributions in the Pacific sector of the Arctic Ocean in summer 2008 were tightly linked to the FWC in the upper surface layer. Regions strongly affected by freshening, such as ice-free basins $\left(73^{\circ}-77^{\circ} \mathrm{N}\right)$ and heavily icecovered areas $\left(83^{\circ}-86^{\circ} \mathrm{N}\right)$ displayed the lowest PP, lowest surface Chla (nutrient limitation) and a deep and weakly productive sub-surface chlorophyll- $a$ maximum (nutrient and light limitations). In contrast, "hot spots", with 2 to 5 times higher Chla and PP values than generally found in the deep basins, were observed across the offshore marginal ice zone (MIZ) over the Chukchi Borderland $\left(77^{\circ}-82^{\circ} \mathrm{N}\right)$. The recent break-up of sea ice at the higher most latitudes allowed phytoplankton to thrive on the nutrient deeper pool. These transition zones between ice-covered and ice-free waters experienced lower FWC and nutrient replenishment of surface waters from the underlying Pacific waters. Nevertheless, stimulation of the primary producers of the MIZ was not significant in the Canada Basin, more affected by the freshening than the Chukchi Borderland due to Beaufort Gyre. Similarly, the ice-free Canada Basin experienced a $15 \mathrm{~m}$ deeper nutrient depletion than the ice-free Chukchi Abyssal Plain, less affected by the Beaufort Gyre. The Chukchi shelf, with the lower FWC, was the most productive area of the cruise with biomasses and primary production values in the range of those reported in previous summer studies in that area. The highest Chla values in the northern shelf were associated to upwelling cells of nutrient-rich waters at the shelf break while the highest PP observed in the south were sustained by nutrient-rich Pacific waters entering the Bering Strait.

While ice cover seems to play a key role in triggering phytoplankton growth, the FWC 
appears to be a crucial factor of the phytoplankton response to summer sea ice retreat, by

614

615

616

617

618

619

620

621

622 acting on the nutrient reservoir depth. Overall, our results suggest that in the context of future global warming, the reduction of nutrient availability due to increase FWC could counteract the expected phytoplankton response to sea ice retreat, i.e. an increase of biomass and PP due to enhanced light penetration and a longer growing season.

\section{Acknowledgements}

This research is a contribution to the Arctic Tipping Points (ATP) project (http://www.eu-atp.org) funded by FP7 of the European Union (contract \#226248) and the European program DAMOCLES (Developing Arctic Modeling and Observing Capabilities for Long-term Environmental Studies, 2007-2010) and Chinese IPY program/National Natural Science Foundation of China (No. 41076135). Support for Lee was provided by the Korea Research Foundation (KRF) grant funded by the Korea government (MEST) (No. 2011-0007761). We express our gratitude to the captain and the crew of the Chinese icebreaker Xuelong for the opportunity to take part in the fieldwork in the Arctic Ocean. We thank Chinese Arctic and Antarctic Administration extending an invitation to French scientists from the LOCEAN laboratory (UPMC - Université de Pierre et Marie Curie) to participate in the CHINARE cruise. We especially thank the SIOSOA (Hangzhou, China) for supporting the stay of French scientists in their laboratory and the pigment analysis (by HPLC), as well as their warm welcome and helpfulness. We are grateful to Mr S. Q. Gao, Y. Lu and Ms. H. Jin (SIO-SOA, Hangzhou, China) for their help in the nutrient analysis and sample collection, as well as professor J.P. Zhao (Ocean University China, Qingdao, China) and the Chinese and Finnish physical teams (Finnish Meteorological Institute, Helsinki) for the acquisition and transfer of the hydrological data (CTD). Philippe Lattes is warmly thanked for his help in the creation of several computer programs used to interpret the data.

\section{References}

Anderson, L. G., Jones, E. P., and Rudels, B.: Ventilation of the Arctic Ocean estimated by a plume entrainment model constrained by CFCs, Journal of Geophysical Research-Oceans, 104, 13423-13429, 1999.

Anderson, L. G., Tanhua, T., Björk, G., Hjalmarsson, S., Jones, E. P., Jutterström, S., Rudels, B., Swift, J. H., and Wåhlstöm, I.: Arctic ocean shelf-basin interaction: An active continental shelf CO2 pump and its impact on the degree of calcium carbonate solubility, Deep Sea Research Part I: Oceanographic Research Papers, 57, 869$879,2010$.

Ardyna, M., Gosselin, M., Michel, C., Poulin, M., and Tremblay, J. E.: Environmental forcing of phytoplankton community structure and function in the Canadian High Arctic: contrasting oligotrophic and eutrophic regions, Marine Ecology Progress Series, 442, 37-57, 2011.

Arrigo, K. R., van Dijken, G., and Pabi, S.: Impact of a shrinking Arctic ice cover on marine primary production, Geophysical Research Letters, 35, L19603, 2008.

Bates, N. R., Moran, S. B., Hansell, D. A., and Mathis, J. T.: An increasing CO2 sink in the Arctic Ocean due to sea-ice loss, Geophysical Research Letters, 33, L23609, 2006.

Cai, W. J., Chen, L., Chen, B., Gao, Z., Lee, S. H., Chen, J., Pierrot, D., Sullivan, K., Wang, Y., Hu, X., Huang, W. J., Zhang, Y., Xu, S., Murata, A., Grebmeier, J. M., Jones, E. P., and Zhang, H.: Decrease in the CO2 uptake capacity in an ice-free Arctic Ocean basin, Science, 329, 556-559, 2010.

Carmack, E. and Chapman, D. C.: Wind-driven shelf/basin exchange on an Arctic shelf: The joint roles of ice cover extent and shelf-break bathymetry, Geophysical Research Letters, 30, 1778, 2003.

Carmack, E. and Wassmann, P.: Food webs and physical-biological coupling on pan-Arctic shelves: Unifying concepts and comprehensive perspectives, Progress in Oceanography, 71, 446-477, 2006.

Chessel, D., Dufour, A. B., and Thioulouse, J.: The ade4 package-I-One-table methods, R news, 4, 5-10, 2004.

Codispoti, L. A., Flagg, C., Kelly, V., and Swift, J. H.: Hydrographic conditions during the 2002 SBI process 
experiments, Deep-Sea Res Pt Ii, 52, 3199-3226, 2005.

Comiso, J. C., Parkinson, C. L., Gersten, R., and Stock, L.: Accelerated decline in the Arctic sea ice cover, Geophysical Research Letters, 35, L01703, 2008.

Cota, G. F., Pomeroy, L. R., Harrison, W. G., Jones, E. P., Peters, F., Sheldon, W. M., and Weingartner, T. R.: Nutrients, primary production and microbial heterotrophy in the southeastern Chukchi Sea: Arctic summer nutrient depletion and heterotrophy, Marine Ecology Progress Series, 135, 247-258, 1996.

Coupel, P., Jin, H. Y., Joo, M., Horner, R., Bouvet, H. A., Sicre, M. A., Gascard, J. C., Chen, J. F., Garçon, V., and Ruiz-Pino, D.: Phytoplankton distribution in unusually low sea ice cover over the Pacific Arctic, Biogeosciences, 9, 4835-4850, 2012.

Frey, K. E., Perovich, D. K., and Light, B.: The spatial distribution of solar radiation under a melting Arctic sea ice cover, Geophysical Research Letters, 38, L22501, 2011.

Giles, K. A., Laxon, S. W., Ridout, A. L., Wingham, D. J., and Bacon, S.: Western Arctic Ocean freshwater storage increased by wind-driven spin-up of the Beaufort Gyre, Nature Geoscience, 5, 194-197, 2012.

Gordon, L. I., Jennings Jr, J. C., Ross, A. A., and Krest, J. M.: A suggested protocol for continuous flow automated analysis of seawater nutrients (phosphate, nitrate, nitrite and silicic acid) in the WOCE Hydrographic Program and the Joint Global Ocean Fluxes Study, WOCE Operations Manual, Part, 3, 91-91, 1993.

Gosselin, M., Levasseur, M., Wheeler, P. A., Horner, R. A., and Booth, B. C.: New measurements of phytoplankton and ice algal production in the Arctic Ocean, Deep Sea Research Part II: Topical Studies in Oceanography, 44, 1623-1644, 1997.

Grasshoff, K. and Ehrhardt, M.: K. Kremling (1983): Methods of Seawater Analysis. Weinheim: Verlag Chemie, 1983.

Hameedi, M. J.: Aspects of water column primary productivity in the Chukchi Sea during summer, Marine Biology, 48, 37-46, 1978.

Hill, V. and Cota, G.: Spatial patterns of primary production on the shelf, slope and basin of the Western Arctic in 2002, Deep Sea Research Part II: Topical Studies in Oceanography, 52, 3344-3354, 2005.

Jinping, Z., Weibo, W., and Lee, C.: Calculation of photosynthetically available radiation using multispectral data in the Arctic, Chinese Journal of Polar Research, 2, 2010.

Johnson, M. A. and Polyakov, I. V.: The Laptev Sea as a source for recent Arctic Ocean salinity changes, Geophysical Research Letters, 28, 2017-2020, 2001.

Jones, E. P., Anderson, L. G., Jutterstr^m, S., Mintrop, L., and Swift, J. H.: Pacific freshwater, river water and sea ice meltwater across Arctic Ocean basins: Results from the 2005 Beringia Expedition, Journal of Geophysical Research, 113, C08012, 2008.

Lee, S., Stockwell, D., and Whitledge, T.: Uptake rates of dissolved inorganic carbon and nitrogen by under-ice phytoplankton in the Canada Basin in summer 2005, Polar Biology, 33, 1027-1036, 2010.

Lee, S. H. and Whitledge, T. E.: Primary and new production in the deep Canada Basin during summer 2002, Polar Biology, 28, 190-197, 2004.

Legendre, P. and Legendre, L.: Numerical ecology, Elsevier, 2012.

Li, W. K., McLaughlin, F. A., Lovejoy, C., and Carmack, E. C.: Smallest algae thrive as the Arctic Ocean freshens, Science, 326, 539, 2009.

Longhurst, A. R.: Role of the Marine Biosphere in the Global Carbon-Cycle, Limnology and Oceanography, 36 , 1507-1526, 1991.

Lu, P., Li, Z., Cheng, B., Lei, R., and Zhang, R.: Sea ice surface features in Arctic summer 2008: Aerial observations, Remote Sensing of Environment, 114, 693-699, 2010.

Maslanik, J., Stroeve, J., Fowler, C., and Emery, W.: Distribution and trends in Arctic sea ice age through spring 2011, Geophysical Research Letters, 38, L13502, 2011.

Mauritzen, C.: Oceanography Arctic Freshwater, Nature Geoscience, 5, 162-164, 2012.

McLaughlin, F. A. and Carmack, E. C.: Deepening of the nutricline and chlorophyll maximum in the Canada Basin interior, 2003-2009, Geophysical Research Letters, 37, L24602,, 2010.

McPhee, M. G., Proshutinsky, A., Morison, J. H., Steele, M., and Alkire, M. B.: Rapid change in freshwater content of the Arctic Ocean, Geophysical Research Letters, 36, L10602, 2009.

Melnikov, I. and Kolosova, E.: The Canada Basin zooplankton in recent environmental changes in the Arctic Ocean, Proceedings of the Arctic Regional Centre, "Changes in the atmosphere-land-sea system in the Amerasian Arctic, 3, 165-176, 2001.

Morison, J., Kwok, R., Peralta-Ferriz, C., Alkire, M., Rigor, I., Andersen, R., and Steele, M.: Changing Arctic Ocean freshwater pathways, Nature, 481, 66-70, 2012.

Mundy, C. J., Gosselin, M., Ehn, J., Gratton, Y., Rossnagel, A., Barber, D. G., Martin, J., Tremblay, J.-É., Palmer, M., Arrigo, K. R., Darnis, G., Fortier, L., Else, B., and Papakyriakou, T.: Contribution of under-ice primary production to an ice-edge upwelling phytoplankton bloom in the Canadian Beaufort Sea, Geophysical Research Letters, 36, L17601, 2009.

Nicolaus, M., Katlein, C., Maslanik, J., and Hendricks, S.: Changes in Arctic sea ice result in increasing light 
transmittance and absorption, Geophysical Research Letters, 39, 2012.

Niebauer, H. J. and Alexander, V.: Oceanographic Frontal Structure and Biological Production at an Ice Edge, Continental Shelf Research, 4, 367-388, 1985.

Pabi, S., van Dijken, G. L., and Arrigo, K. R.: Primary production in the Arctic Ocean, 1998-2006, Journal of Geophysical Research, 113, 2008.

Perovich, D. K.: The Changing Arctic Sea Ice Cover, Oceanography, 24, 162-173, 2011.

Perovich, D. K., Richter-Menge, J. A., Jones, K. F., and Light, B.: Sunlight, water, and ice: Extreme Arctic sea ice melt during the summer of 2007, Geophysical Research Letters, 35, L11501, 2008.

Peterson, B. J., McClelland, J., Curry, R., Holmes, R. M., Walsh, J. E., and Aagaard, K.: Trajectory shifts in the Arctic and subarctic freshwater cycle, Science, 313, 1061-1066, 2006.

Poulin, M., Daugbjerg, N., Gradinger, R., Ilyash, L., Ratkova, T., and Quillfeldt, C.: The pan-Arctic biodiversity of marine pelagic and sea-ice unicellular eukaryotes: a first-attempt assessment, Marine Biodiversity, 41, 13-28, 2010.

Rabe, B., Karcher, M., Schauer, U., Toole, J. M., Krishfield, R. A., Pisarev, S., Kauker, F., Gerdes, R., and Kikuchi, T.: An assessment of Arctic Ocean freshwater content changes from the 1990s to the 2006-2008 period, Deep Sea Research Part I: Oceanographic Research Papers, 58, 173-185, 2011.

Rainville, L., Lee, C., and Woodgate, R.: Impact of Wind-Driven Mixing in the Arctic Ocean, Oceanography, 24, 136-145, 2011.

Reigstad, M., Wassmann, P., Wexels Riser, C., Øygarden, S., and Rey, F.: Variations in hydrography, nutrients and chlorophyll a in the marginal ice-zone and the central Barents Sea, Journal of Marine Systems, 38, 9-29, 2002.

Sambrotto, R. N., Goering, J. J., and McRoy, C. P.: Large yearly production of phytoplankton in the Western bering strait, Science, 225, 1147-1150, 1984.

Sarmiento, J. L. and Gruber, N.: Ocean biogeochemical dynamics, Princeton University Press Princeton, 2006.

Semiletov, I., Savelieva, N., Weller, G., Pipko, I., Pugach, S., Gukov, A. Y., and Vasilevskaya, L.: The dispersion of Siberian river flows into coastal waters: Meteorological, hydrological and hydrochemical aspects. In: The freshwater budget of the Arctic Ocean, Springer, 2000.

Serreze, M. C., Barrett, A. P., Slater, A. G., Woodgate, R. A., Aagaard, K., Lammers, R. B., Steele, M., Moritz, R., Meredith, M., and Lee, C. M.: The large-scale freshwater cycle of the Arctic, Journal of Geophysical Research, 111, C11010, 2006.

Springer, A. M. and McRoy, C. P.: The paradox of pelagic food webs in the northern Bering Sea-III. Patterns of primary production, Continental Shelf Research, 13, 575-599, 1993.

Stroeve, J. C., Serreze, M. C., Holland, M. M., Kay, J. E., Malanik, J., and Barrett, A. P.: The Arctic's rapidly shrinking sea ice cover: a research synthesis, Climatic Change, 110, 1005-1027, 2011.

Strong, C. and Rigor, I. G.: Arctic marginal ice zone trending wider in summer and narrower in winter, Geophysical Research Letters, 40, 4864-4868, 2013.

Thomson, R. E. and Emery, W. J.: Data analysis methods in physical oceanography, Elsevier, 2001.

Tremblay, J.-É. and Gagnon, J.: The effects of irradiance and nutrient supply on the productivity of Arctic waters: a perspective on climate change, Nato Sci Peace Secur, doi: 10.1007/978-1-4020-9460-6_7, 2009. 73-93, 2009.

Tremblay, J. E., Belanger, S., Barber, D. G., Asplin, M., Martin, J., Darnis, G., Fortier, L., Gratton, Y., Link, H., Archambault, P., Sallon, A., Michel, C., Williams, W. J., Philippe, B., and Gosselin, M.: Climate forcing multiplies biological productivity in the coastal Arctic Ocean, Geophysical Research Letters, 38, L18604, 2011.

Tremblay, J. E., Gratton, Y., Fauchot, J., and Price, N. M.: Climatic and oceanic forcing of new, net, and diatom production in the North Water, Deep-Sea Res Pt Ii, 49, 4927-4946, 2002.

Tremblay, J. E., Michel, C., Hobson, K. A., Gosselin, M., and Price, N. M.: Bloom dynamics in early opening waters of the Arctic Ocean, Limnology and Oceanography, 51, 900-912, 2006.

Tremblay, J. E., Robert, D., Varela, D. E., Lovejoy, C., Darnis, G., Nelson, R. J., and Sastri, A. R.: Current state and trends in Canadian Arctic marine ecosystems: I. Primary production, Climatic Change, 115, 161-178, 2012.

Wassmann, P. and Reigstad, M.: Future Arctic Ocean Seasonal Ice Zones and Implications for Pelagic-Benthic Coupling, Oceanography, 24, 220-231, 2011.

Weingartner, T., Aagaard, K., Woodgate, R., Danielson, S., Sasaki, Y., and Cavalieri, D.: Circulation on the north central Chukchi Sea shelf, Deep Sea Research Part II: Topical Studies in Oceanography, 52, 3150-3174, 2005.

Wood, E. D., Armstron.Fa, and Richards, F. A.: Determination of Nitrate in Sea Water by Cadmium-Copper Reduction to Nitrite, Journal of the Marine Biological Association of the United Kingdom, 47, 23-31, 1967.

Woodgate, R. A. and Aagaard, K.: Revising the Bering Strait freshwater flux into the Arctic Ocean, Geophysical Research Letters, 32, L02602, 2005.

Woodgate, R. A., Aagaard, K., and Weingartner, T. J.: A year in the physical oceanography of the Chukchi Sea: Moored measurements from autumn 1990-1991, Deep Sea Research Part II: Topical Studies in Oceanography, 
52, 3116-3149, 2005.

Yamamoto-Kawai, M., McLaughlin, F. A., Carmack, E. C., Nishino, S., Shimada, K., and Kurita, N.: Surface freshening of the Canada Basin, 2003-2007: River runoff versus sea ice meltwater, Journal of Geophysical Research, 114, C00A05, 2009.

Yun, M. S., Whitledge, T. E., Kong, M., and Lee, S. H.: Low primary production in the Chukchi Sea shelf, 2009, Continental Shelf Research, 76, 1-11, 2014.

Zhang, J., Ashjian, C., Campbell, R., Hill, V., Spitz, Y. H., and Steele, M.: The great 2012 Arctic Ocean summer cyclone enhanced biological productivity on the shelves, Journal of Geophysical Research: Oceans, 119, 297 312, 2014.

789 
- The freshwater content (FWC) appears to be a crucial factor of the phytoplankton response to summer sea ice retreat, by acting on the nutrient reservoir depth.

- The strong freshening observed in the Canada Basin had a negative impact on primary producers.

- Biomasses accumulation and relatively high primary production were observed across the offshore marginal ice zone.

- The Chukchi shelf, with the lower FWC, was the most productive area of the cruise with biomasses and primary production values in the range of previous studies. 